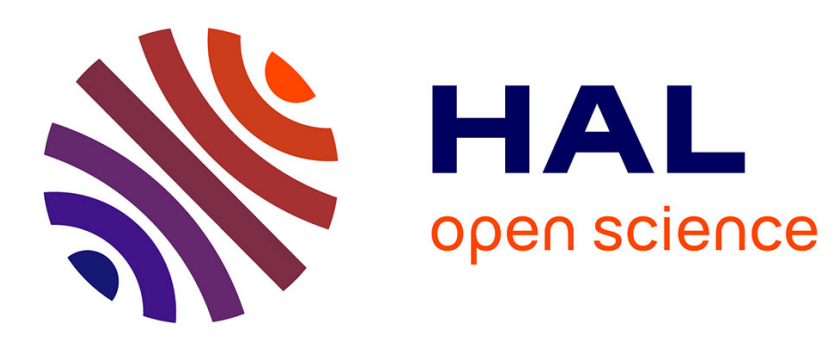

\title{
Organizations in the Fog: An Investigation into the Dynamics of Knowledge \\ Philippe Baumard
}

\section{To cite this version:}

Philippe Baumard. Organizations in the Fog: An Investigation into the Dynamics of Knowledge. B. Moingeon, A. Edmondson (Eds.). Organizational Learning and Competitive Advantage, Sage, pp. 74-92, 1996. hal-03230959

\section{HAL Id: hal-03230959 https://hal.science/hal-03230959}

Submitted on 20 May 2021

HAL is a multi-disciplinary open access archive for the deposit and dissemination of scientific research documents, whether they are published or not. The documents may come from teaching and research institutions in France or abroad, or from public or private research centers.
L'archive ouverte pluridisciplinaire $\mathbf{H A L}$, est destinée au dépôt et à la diffusion de documents scientifiques de niveau recherche, publiés ou non, émanant des établissements d'enseignement et de recherche français ou étrangers, des laboratoires publics ou privés. 


\title{
Organizations in the Fog: An Investigation into the Dynamics of Knowledge
}

Reference :Baumard, Philippe (1996), "Organizations in the Fog: An Investigation into the Dynamics of Knowledge". In: Bertrand Moingeon and Amy Edmondson (eds.), Organizational Learning and Competitive Advantage. London: Sage, pp.74-91.

\author{
Philippe Baumard \\ Tenured Professor of Organizational Theory \\ Cnam - École Polytechnique
}

This paper discusses the dialectics between ambiguity and knowledge. The conventional view is that the relevant knowledge comes from explicit situational analysis, i.e. it is objective knowledge. In contradiction with a positivist notion of knowledge that views it merely as "information enriched with meaning and experience," we argue that cognitive and organizational issues should no longer be approached separately. By identifying the role played by particular types of knowledge in the step of resolving an ambiguous situation, we try to enlighten the role played by the richness, the density and the versatility of knowledge. 


\title{
Competitive Advantage from Tacit Knowledge: Bringing some empirical evidence
}

\author{
Philippe Baumard \\ Université de Paris IX-Dauphine \\ Centre de Recherches DMSP - Bureau D 515 \\ Place Maréchal de Lattre de Tassigny \\ 75116 PARIS - FRANCE
}

\section{Introduction}

It seems to be common knowledge that today's competitive organizations are those which can be qualified as "innovative," "intelligent" or "flexible". It is, however, not clear what stands behind those words. This paper focuses on organizations that derive their competitive advantage from their "effectiveness in ambiguity," an expression used by Herzberg (1987) to define "intelligence." Thus, we focus on organizations that remain competitive in the worst conditions. The firms lose their way, the executives' vision becomes fogged. The strategic task is then to restore "clarity" - as opposed to "ambiguity" - by generating new knowledge, or by transforming the existing knowledge, to "get out of the fog."

In order to analyze the different movements of knowledge within organizations facing an ambiguous situation, a two-by-two matrix inspired by Spender $(1993,1994)$ and Nonaka $(1991 ; 1993 ; 1994)$ is elaborated. Two distinctions are made. One is explicit/tacit, familiar from Polanyi's work $(1966,1958)$, and the other is the individual/social, familiar from Durkheimian sociology. To avoid misinterpretations, we will use an individual/collective dimension (as used by Nonaka).

As we look for the basis of a "grounded theory" (Glaser, Strauss, 1967) of organizational knowledge dynamics, we investigate into the workplace the managers' behaviors and knowledge mutations as an ambiguous and unpredictable situation has to be faced. We unpack the role played by the above four types of knowledge (explicit/individual; explicit/collective; tacit/individual; tacit/collective) as we see organizations moving around the matrix as they try to deal with various ambiguous situations. We thus unveil tacit knowledge as a source of competitive advantage. Case study research was conducted in France (1991-1992), Australia (University of Technology, Sydney, 1992-1993), and in the US (New York University, 19931994).

\section{Defining Ambiguity}

Ambiguity is a concept that is scarcely used in the management literature, at least, rarely used in its appropriate meaning. Characteristically, ambiguity is often confused with uncertainty, from which it differs in many ways. The word's etymology comes from the Latin ambo (two). The word expresses the impossibility to decide upon a definite meaning of a situation, a sentence, a word, a thought, an action or a person. For example, oracles are tradi- 
tionally ambiguous. They offer many interpretations, while never being trapped in one definite meaning. In rhetorics, ambiguity is used as a technique to leave the audience uncertain about the meaning of an assertion, and then to play with the different potential meanings of this assertion. In Racine's Andromaque, Pyrrhus says to Andromaque: "You hate me more than all the Greeks together." We have here the simultaneous presence of two (ambo-) possible meanings : (a) Andromaque hates Pyrrhus more than the Greeks hate him; (b) Andromaque hates Pyrrhus more than she hates the Greeks.

Uncertainty is altogether a different concept. While ambiguity is attached to the notion of meaning, uncertainty is defined as the characteristic of an event that is not determined. Uncertainty can apply to a situation that is known, clear and identified. The fate of the Pisa tower is uncertain. It may fall or it may not, but there is nothing ambiguous about the inclination of the Pisa tower (it is, indeed, inclined, and a measure of the inclination can be taken). Ambiguity is about the simultaneity of two or more meanings that we cannot weigh, while probabilities may apply more easily to the weight of an uncertain event.

Observing ambiguous situations is dealing with situations where nothing is permanent, nothing is true, nothing is false. Or all is true, all is false, as noted by Rosset (1985). With the multiplication of potential meanings, "every way leads to Rome," notes Rosset, so that "no particular way leads specifically to Rome." The organizations we study are in such situations. The certainty/uncertainty of their choices is impossible to determine.

\section{Struggling With Ambiguity}

Neither systematically deterministic, nor spontaneously voluntaristic, organizations work under sets of minima (minimal consistency, minimal faith, minimal contentment, etc.), "weathering the storm," "unlearning yesterday" in order to continue to "fly without flying apart," while "proliferating processes collide, contest, and interact with another to generate wisdom" (Hedberg, Nystrom, Starbuck, 1976). In the maintenance of this minima, managers try to make sense of the stimuli they perceive. Subsequently, "those interpretations are generated within the organization in the face of considerable perceptual ambiguity" (March, Olsen, 1976, p. 19). First, we do not notice everything. As R.D. Laing put it : "The range of what we think and do, is limited by what we fail to notice. And because we fail to notice that we fail to notice, there is little we can do to change, until we notice, how failing to notice shapes our thoughts and deeds" (quoted by Goleman, 1985, p.24). And to start to notice that we fail to notice, we need to deploy considerable efforts, and to struggle with contradictory stimuli, which carry many antithetical meanings: a permanent struggle with ambiguity.

\section{Freaking out in the fog: ambiguity as an obstacle to decision making}

"Struggling with ambiguity" (Alvesson, 1993) can thus condition the fate of an organization. For instance, tolerance to ambiguity has been identified as a critical factor of success when dealing in foreign countries, amongst others' cultures (Marquardt, Engel, 1993). While decision theorists try to improve and rationalize what they would optimistically call the "human thinking system," in real life, "people do not know all of the sources of stimuli, nor do they necessarily know how to distinguish relevant from irrelevant information" (Starbuck, Miliken, 1988, p.41). People act according to "criteria" that they view as important, sometimes quite unable to define why these criteria are important, sometimes totally ignoring, or forgetting why they decided that these criteria were important, for individuals have the 
tendency "to deal with a limited set of problems and a limited set of goals" (March, Cyert, 1963, p. 117). "Bounded rationality," i.e. searching for answers in the direct neighborhood of the problem source, thus stands as another struggle with ambiguity. "Perceptual filtering" (Starbuck, Miliken, 1988) is another human "mechanism" used to struggle with ambiguity. All we do is, distantly or closely, loosely or tightly, deliberately or unconsciously, linked to the primary human activity of struggling with an environment in which clarity can never be taken for granted. And because we have "to live with complexity" (Starbuck, Miliken, 1988, p. 58), we can learn and "unlearn" (Hedberg, 1981). As the Greek philosophers and rhetorists were delighted to teach to their scholars, elaborating ambiguity is a healthy attitude to "learn to learn" and "to learn to doubt." But, "how capable then are organizations to unlearn old behaviors and world views and to relearn when they face new situations? Several authors have expressed pessimistic views on this matter" (Hedberg, 1981, p. 18).

\section{Thriving in the fog : the tactical use of ambiguity}

In the preceding section, we reviewed how the literature most commonly portrays ambiguity as an obstacle to decision-making. In this section we will see that ambiguity can be actively sought and enacted for many tactical purposes.

One of the domains where ambiguity might be sought is language. Managers tend to be less precise about their purposes in bureaucratic environments in order to protect their personal space. Thus, by using loose role definitions or avoiding direct confrontation, they maintain a "blur zone" (Crozier, Hedberg, 1977). A loose role definition, used with accordingly ambiguous language, can be of tactical use when role conflicts arise (Shenkar, Zeira, 1992). Thus, ambiguous language can be a mean of competitive advantage when used with cunning. Détienne and Vernant, in their study of cunning intelligence in ancient Greece (1974), show how politicians and sophists used this kind of "oblique knowledge" to deal with "ambiguous, shifting and disconcerting situations." Nowadays, ambiguous language may be used as well to manipulate voters (Dacey, 1976). Ambiguity may eventually be the wisest choice when dealing with politics (Alesina, Cukierman, 1990). This finding is skillfully demonstrated by politicians as they run for presidencies.

Reacting to the tradition which has reduced rhetorics to summaries of rules and principles, Covino (1988) identifies rhetoric as an art of creating purposeful ambiguity. Fighting the well-spread assumption that rhetoric is a technique with no other purpose than pedagogical, Covino reviewed Plato's Phaedrus, Aristotle's Rhetoric, and Cicero's De Oratore, along with Michel de Montaigne, Giambattista Vico, and David Hume, noting that such spirit of questing and ambiguity contributes to a strong resistance to a positivistic epistemology that exalts knowledge-as-information.

Following Covino's footsteps, using a psychological perspective, Gregory (1988) states that all human observations are perceptually, and also conceptually, ambiguous. Recalling to readers the philosopher's "sense" vs. "sensation" dilemma, Gregory concludes that elaborating ambiguity is part of our sense-making, for we all try, from sensations that are essentially private and personal, to make these sensations the basis of objective knowledge.

When the potential presidential candidate plays with words when asked about his intentions, he does nothing but play on the "sense" vs. "sensation" dilemma. He allows ambiguity with the tactical purpose of preserving some alternatives which to maneuver. Will he be a candi- 
date? With whom and against whom ? The voter is left with a mutable and loose sensation that "he might," and with a strong sense that "he may."

\section{Research Method}

The objective of our empirical research is to identify in the workplace the existence of specific modes of knowing in "ambiguous, mutable and unpredictable" situations and thus to answer the following questions:

- In organizations' struggles with ambiguity, can we identify a type of knowledge from our $2 \times 2$ matrix that is dominant at a particular time?

- If so, how can moving around the matrix help organizations to succeed in their struggle with ambiguity?

- Can organizations derive a competitive advantage from such a dynamic handling of their organizational knowledge?

\section{Revelatory situations \& purposeful sampling}

We used multiple case study research (Glaser, Strauss, 1967; Lincoln, Guba, 1985) to investigate the phenomenon of organizational ambiguity within its real-life context. The rationale for the choice of multiple case study research was "producing evidence that the four cases did indeed involve the same syndrome" (Yin, 1984). Each case had to be carefully selected to be certain that the organization was really facing an ambiguous, unpredictable and mutable situation. Organizations were selected on the peculiarity of situations they were to cope with (unexpected rupture in the course of events, such as sudden political turbulence).

With such criteria, four organizations were finally selected for their communality in attributes of interest (task complexity, highly ambiguous situation) and divergence in other attributes (different countries, different products and services, different purposes). These organizations are Pechiney (France, Guinea), Indosuez (USA), Qantas (Australia) and Indigo (France).

Not to recall Schon's "reflective practitioners" $(1983,1988)$,

\section{Engaging interviewees in "reflective practice"}

"Reflective practice" is thinking about and critically analyzing one's actions with the goal of improving one's professional practice (Kottkamp, 1990; Osterman, 1990; Peters, 1991). "Engaging in reflective practice requires individuals to assume the perspective of an external observer in order to identify the assumptions and feelings underlying their practice and then to speculate about how these assumptions and feelings affect practice" (Imel, 1992). Reflective practice finds its roots in the works of Dewey, Lewin and Piaget, "each of whom advocated that learning is dependent upon the integration of experience with reflection and of theory with practice" (Imel, 1992, p. 1). We were interested in reflective practice as a research method because it fits perfectly with a naturalistic and empirical inquiry of tacit knowledge as a competitive advantage in ambiguous situations. On one hand, "reflective practice" is a process of making sense of one's own practice, during or after the action has taken place (Osterman, 1990). This seems to be one of the main activities of a person or a group of persons facing "ambiguity": trying to make sense. On the other hand, reflective practice is one's own investigation in his or her own "knowledge system." Thus, we see 
reflective practice as an excellent tool to identify, within this knowledge, which part is tacit or explicit, individual or collective.

Last, but not least, argument in favor of using "reflective practice" as a research tool is its versatility. It can be used as people are "knowing in action" (Schon, 1988), or ad hoc, with the purpose of asking people to lead a "reflection on their action". Thus, it fits with various research designs, especially those dedicated to qualitative data analysis (Miles, Hubermann, 1984), as in-site, in-process analysis can be required along with ad-hoc and post-data gathering analysis ("reflection in action" versus "reflection on action"). This method gives the opportunity to measure one's own perception gap between what he thinks to be - in action - his "way" to manage knowledge, and what he finally discovers it to be $a$ posteriori. Kortkamp (1990) uses the terms "off-line" and "on-line" to distinguish between these two modes of reflection (in-action/on-action). By this method, the researcher plays the role of a "catalyst," helping out the interviewees to become aware of the contradictions between what they do and what they believe they do (Osterman, 1990; Schon, 1988). Here the researcher may pay all his attention to many research biases including the great sensitivity of people when they have to examine their own beliefs, values and feelings (Peters, 1991; Rose, 1992). Moreover, Lasley (1989) warns about the limits of reflective practice: it requires both knowledge of practice and awareness of professional and personal philosophy. "Reflection without an understanding of the rules or techniques that constitute good practice may lead to a repetition of mistakes, whereas reflection without philosophical awareness can lead to a preoccupation with technique" (Imel, 1992, p.2). To conduct interviews and to play adequately the role of "catalyst," we will follow the rules that Peters (1991, pp. 91-95) enunciated in a process he called DATA: "describe, analyze, theorize, and act."

\section{Completing "reflective practice" with direct observation}

However, as Schon (1983, p. 51) judiciously noticed, much of the "skillful action reveals a knowing more than we can say," using here Polanyi's words to define tacit knowledge: "Knowing more than we can tell" (Polanyi, 1966). Thus, we cannot entirely rely on what managers have to tell us about their "way" to manage knowledge. First, it may happen that they don't know that they know, or more likely, that they do not know at all. For this reason, we will use a second method, which is direct observation. This however implies that the researcher must be present when (a) the person discovers the ambiguous situation (emergence), (b) when this person deals with ambiguity by using different types of knowledge (explicit, tacit, individual, collective) and, finally, (c) when this person escapes, avoids, or thrives in this ambiguity to achieve his or her purpose.

\section{Reaching "triangulation" by using different sources of data}

Multiple sources of evidence were gathered to obtain a triangulation of observation methods and to maintain a chain of evidence (Yin, 1984). Letters, memoranda, communiqués, agendas, announcements, administrative documents (proposal, mission reports), news clippings and articles appearing in the mass media were major sources of secondary data. In the Pechiney case - the studied events having occurred in the late 1920s and 1950s complementary archival records were used (organizational records, organization notes, CEOs' diaries). Direct observation in sites was intensively used with an average visit of six months in studied organizations. Direct observations were made throughout the field visit, "including those occasions during which other evidence, such as that of interviews, was being 
collected" (Yin, 1984, p. 91). In-depth interviews were used to ask key respondents for "for the facts of a matter as well as for the respondents' opinions about the events" (Yin, 1984, p. 89). Interviews were of an open-ended nature, with several recurrences and opportunity for feed-back from respondents. The respondents' population included people involved and not involved in the studied processes, so as to measure the awareness of these processes in the organization and to understand the articulation of the different types of knowledge. The research finally involved 70 series of interviews (from 10 to 25 , according to the size of the studied organization).

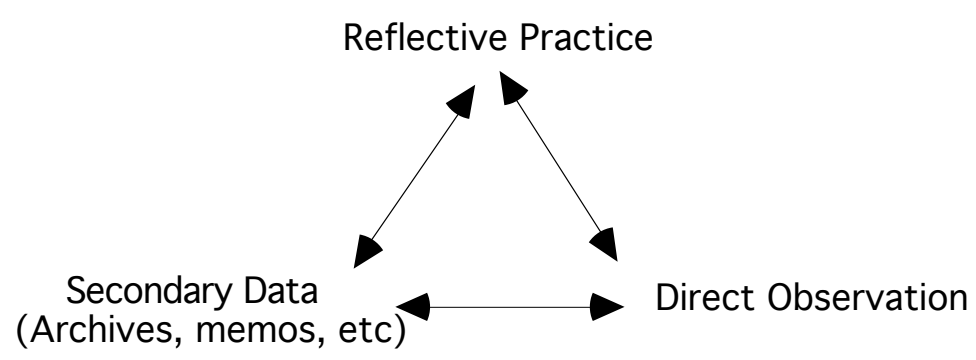

Fig. 1: Triangulation of qualitative methods

\section{Data Analysis}

Reliability of theory construction relies on a "process that must be designed to highlight relationships, connections, and interdependencies in the phenomenon of interest" because "researchers cannot make deductions from concepts alone" (Weick, 1989, p. 517). Unlike positivistic research, inductive research "lacks a generally accepted model for its central creative process" (Eisenhardt and Bourgeois, 1988). In the absence of a model, data analysis has been focused on a chronological study of agendas and events, trying to identify for each phase what kind of knowledge plays what exact role (individual/collective, explicit/tacit), based on a categorization partly inspired from previous findings (Hedlund, Nonaka, 1991). The purpose is finally to identify and to test the validity of a peculiar knowledge process that handles mutability and unpredictability.

Case descriptions were developed by combining the accounts of each respondent and by direct observation of events whenever possible (all cases apart from Pechiney). Motives and opinions for actions and events that were not observable were included in data sets so as to be preserved for further investigation. That search was complemented by cross-case analysis, and continuous feed-back to respondents to improve both construct validity and adjustments (Eisenhardt, 1989). All data (from reflective practice, interviews, direct observations and archives) were compiled for analysis in tables inspired by Miles and Huberman's (1984) method for qualitative data analysis. The purpose was to identify, for each step of the organizational struggle with ambiguity, what type of knowledge (e.g.. tacit-collective) was mostly used. The outputs were tables relating the frequencies and the purposes of the use of one specific type of knowledge at one particular time. What emerged were propositions shedding light on the conditions surrounding the use of different types/modes of knowledge in the various steps of the organizations' struggles with ambiguity. 


\section{Elaborating the Matrix}

\section{Explicit and collective knowledge}

Explicit and collective knowledge is all the knowledge a community can tell it knows. Spender (1993) used the term "objectified knowledge" to suggest that this knowledge is considered "objective" by the community that shares it. In a positivist understanding, science is a collective and explicit knowledge, though this concept has been challenged by Thomas Kuhn in The Structure of Scientific Revolutions and by Paul Feyerabend in Against Method. For these authors, scientific knowledge is embedded in "paradigms" that are constituted by both scientific discoveries that are commonly acknowledged as valid, and beliefs on the state of the paradigm. Thus, for these authors, scientific researchers should "challenge" (scientific revolutions) existing paradigms in order to help science to progress.

In the organizational body of knowledge, patents, corporate written rules and procedures, organizational charts, management decisions that are known by the whole organization (such as those disseminated through communiqués) are all part of the explicit and collective body of knowledge. Patents, for instance, are the articulation, embedded in written format, of the technical know-how of the firm (Teece, 1987). The purpose of making knowledge explicit and collective can be to disseminate this knowledge to others, to inform people about recent management decisions, to implement new programs and procedures within the organization, or to signal to the "external environment" the organizational purpose and positions, e.g. prices are signals to the competitors and partners of the organization. All explicit and collective knowledge is not systematically explicit or collective in the first place. Rules that are informal and ephemeral can become permanent and explicit through "institutionalization" (DiMaggio, Powell, 1983). "Organizational ceremonies" (Meyer, Rowan, 1977) can also become explicit rituals, and progressively stand for permanent rules.

\section{Explicit and individual knowledge}

We can approach individual and explicit knowledge from two perspectives: the sociological and the technological. From an elementary sociological view, we would say that everything that becomes conscious to us, becomes part of our individual explicit knowledge, i.e. we discover that we belong to a certain group of people in the organization, such as commercial middle managers, for example. As soon as we become aware of this belonging, we acknowledge explicitly in our behavior what has become a "fact". Spender (1993) uses the term "conscious knowledge" to express this type of knowledge.

The other side of individual and explicit knowledge is what we will call our "known-expertise," not to contradict previous findings on expertise that clearly state that the essence of expertise lies in the tacit understanding of rules that are unknown to the beginner or nonexpert. The example of the chess masters used by de Groot $(1946,1965,1966)$ or Newell and Simon (1972) clearly illustrate this point. However, some types of expertise have solely one explicit purpose. The diploma and the titles of doctors have the purpose of communicating the reliability of their services. They may, as well, have the purpose of stating a social and power position, as unveiled by Foucault (1969) in his study of the "statutory knowledge" of doctors in the history of medicine. This type of explicit and individual knowledge, used with 
the purpose of "declaring," has been termed "declarative knowledge" by Polanyi (1958). Positioning and social role consequently play a major part in the transformation and exposure of individual and explicit knowledge.

\section{Tacit and collective knowledge}

We all have some "truths" that we hold collectively. Deception masters of World War II knew it perfectly well (Herbig, Daniel, 1983), and the secret location for "D-Day" was tacitly known by thousands of people ("tacit" being understood here as "to know more than one is willing to tell") without ever being expressed explicitly. Thus, secrecy is maintained on a sociological ground, rather than on the basis of explicit rules alone (Simmel, 1906, 1908). On June $2^{\text {nd }}, 1944$, Verlaine's poetry announces the operation: "Les sanglots longs des violons de l'automne...." The poem was quickly circulated in resistance networks, without ever being translated openly into its real meaning. People knew tacitly that D-Day had come. This tacit circulation of knowledge helps organizations to solve problems that they cannot make explicit. Managers elaborate informal task-forces that work on critical issues in parallel with not exclusive of - formal structures. This "clandestine management" (Moullet, 1992) or these "collateral organizations" (Zand, 1981) often "crystallize" themselves in the course of action. People gather to deal with a specific problem, and naturally gather again when a similar problem arises. This "web of complicities" allows organizations to deal "obliquely" with delicate tasks when formal and explicit processes seem to fail (Baumard, 1994). More generally, we all possess "mental models" (Johnson-Laird, 1983) whose grounds are often collective. In the Challenger disaster, NASA engineers progressively assimilated the Thiokol rubber joints defaults as "acceptable." Although measures were explicitly showing unreliable performances, it became tacitly accepted that this imperfection was after all "normal" (Starbuck, Miliken, 1988a). As Ruddick (1988) put it, when "self-deception is mutual, and the methods communal [...] no one acting in concert has an interest in speaking, or producing evidence, against the false belief or questionable desire that each person wants to maintain."

The main reason behind this scary fact has maybe been revealed by Berger and Luckmann in The Social Construction of Reality (1966). All knowledge is socially constructed. We were born in a "social construction," from which we learned to assimilate and articulate the stimuli around us to formulate our language. In organizations, people belong to "communities of practice" (Lave, Wenger, 1991; Vygotsky, 1962) where they share a practical knowledge which is both a "signature" of their belonging to this community and a major source of change for this community. Many trades are thus learned tacitly and collectively. Masonry apprenticeship is a "learning-by-doing and by-seeing-others-doing-it" process. The tacit and collective know-how of cathedral builders has become legendary. As cathedrals were sometimes built over three or four centuries, generations of cathedral builders transmitted from fathers to sons a know-how for achieving complex tasks, with many of the people being illiterate, without knowledge of reading or writing. Commitment and faith in supra-ordinal goals were part of the process.

Tacit and collective knowledge can also be a guarantee of organizational operational safety. The "collective mind" of flight deck operators (Weick, Roberts, 1993) permits highly complex organizational tasks to be achieved with very few accidents. This "organizational mentality" or "organization mind" (Sandelands, Stablein, 1987) relies upon a tacit 
understanding that does not necessitate explication. Thus, technical knowledge is often acquired through repetitive tasks, which know-how is difficult to communicate. Such is the know-how of the baker, that Nonaka uses as an example (1993), or of the steel worker who "knows" how to approach the metal to cut it properly. Scribner (1986) explains how tacit knowledge is held collectively by workers in a commercial dairy (the warehouse order packers, delivery drivers, and inventory takers). This tacit and collective know-how is difficult to imitate, and can procure a valuable technological rent, allowing the firm to develop an "appropriability regime" (Teece, 1987; Nelson \& Winter, 1987). Many times we say "we know" to express assumptions that seem to be "common sense," while in fact we only express the output of tacit and collective learning (Isaacs, 1950) or things we have learned by traditions whose origins have been forgotten (Nyiri, Smith, 1988). Many elements of our knowledge are gathered from others, without our awareness while we socialize (Nonaka, 1991, 1994; Lewicki, 1986). We assimilate assumptions that are not ours, and personalize or rationalize them, so as to give them our "signature." Eventually, we would say "It's common knowledge," or, "It's common sense" (Spender, 1993).

\section{Tacit and individual knowledge}

As Polanyi (1966) put it, "We know more than we can tell." First, there are many stimuli that we notice without being aware of noticing them. We learn without awareness of what is being learned (Thorndike, Rock, 1934). We cannot communicate what we learn, thus, we are the only ones to be the receivers of this "knowledge." Second, we do not always learn systematically or intentionally. There are many things that we have learned "incidentally" (Jenkins, 1933), because we had the luck to encounter an unexpected learning experience, or because we were focusing on another task, and something "else" was to be learned in this task that we did not expect. In the routine of repetitive tasks, we may also acquire a tacit knowledge concerning the improvement of our task. This "procedural knowledge" (Anderson, 1976; Scribner, 1986) is difficult to share, and when somebody replaces us at our task, the "know-how" is difficult to transmit - a topic that is well-known by quality researchers. Many experts see in the difficulties to implement quality management in the US the difference in attitudes towards learning and knowledge between the US and Japan (Nonaka, Hedlund, 1991). There might be a simple reason for this. As termed by Spender (1993), a large part of our knowledge is "automatic knowledge." We do not know where it comes from, and we cannot tell that we know, though "it's here" and "it works." We encode without awareness of encoding (Hasher, Zacks, 1984). We act mindlessly (Langer, 1978; Langer, Blank \& Chanowitz, 1989). We act instinctively, rely on an "animal knowledge," made of erratic reactions and impulses, based on feelings, smells, guts, like animals do (Griffin, 1982; Morin, 1986). We often rely on a "practical knowledge" (Nyiri, Smith, 1988), which we are not able to isolate, define or describe, for we acquired it through mindless and automatic practice. Some elements of our knowledge were constructed unconsciously, by "serendipity," that is to say, by luck, by imagining a body of knowledge that does not rely upon stimuli, but solely is work of our mind. All this heterogeneous, and rather mysterious, body of knowledge is our "tacit and individual knowledge." 


\section{Moving Around the Matrix}

It would be misleading to state that the above four types of knowledge are independent from each other, and constitute separate and idiosyncratic bodies of knowledge. The dynamics of knowledge are continuous movements, exchanges, and transformations of one type of knowledge into another, whether deliberate or unconscious. To express the speed of these transformations and shifts, a suggestive analogy would certainly be close to the notion of electrical frequencies. Unfortunately we have no clues to know wether the human brain processes these four types of knowledge in parallel or sequentially.

Researching the epistemological and ontological dimensions of knowledge, Nonaka (1990) synthesized the four kinds of transitions between explicit and tacit dimensions of knowledge (Fig. 2). As Nonaka compiled it from different authors (Piaget, Teece, etc.), a specific mode of transition exists for each transformation. For instance, tacit knowledge circulates through socialization, i.e. we learn tacit behaviors, or rules, by interacting and observing other people. This tacit knowledge (e.g. the baker's tacit know-how in preparing bread) can be articulated in more explicit rules (i.e. by using different sets of measures in all various conditions of the process in order to identify the rules that are used tacitly by the baker), and then becomes explicit knowledge. This explicit knowledge can then be combined with other elements of explicit knowledge. For example, two softwares can be merged together. The new set of instructions is a combination of formerly separated sets of instructions included in the two software packages. When we face an explicit set of knowledge, we then have to integrate it into our behavior and practice. We achieve this task through practice of the explicit rules, techniques, scientific findings, etc. We internalize these elements of explicit knowledge in our tacit knowledge and make them ours. .

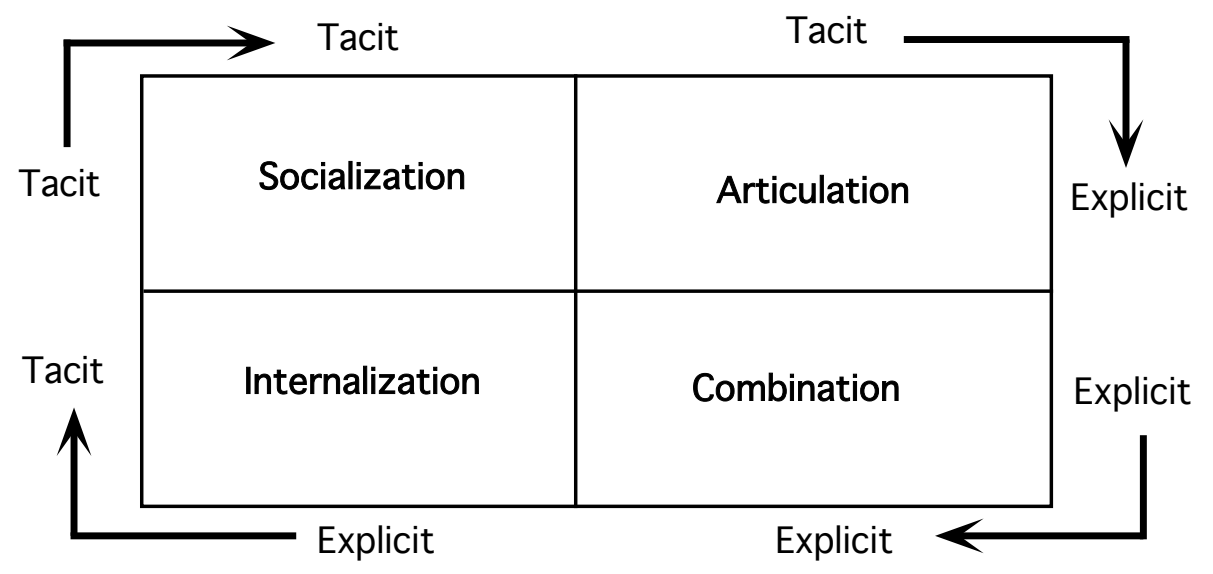

Fig 2.: Transitions from tacit to explicit and vice-versa (Nonaka, 1990)

Using previous findings (Nonaka, 1991, 1992, 1994; Teece, 1987; Winter, 1987; Spender, 1993; Polanyi, 1966), we developed the preceding matrix by integrating the individual and collective dimensions. We finally identified eight forms of transitions in an integrative framework to analyze the different shifts between knowledge types (see Fig. 3). We use these eight forms of transitions in tables inspired by Miles and Huberman (1984) to identify, 
describe and explain when and how they occur in the studied organizations. For instance, we would identify an "appropriability regime" (Teece, 1987) between the knowledge of engineers planning and executing the construction of the Guinean plant, and that of newcomers to the plant. As another example, managers would gather various uncertain or ambiguous stimuli and build a "tacit understanding" of the situation. They would share this understanding by socialization (tacit and collective knowledge) and would learn implicitly to organize this knowledge. Finally, by meeting together and "putting things on the table," they would articulate all their tacit knowledge in one explicit and collective form of knowledge. The elaboration of the following matrix involved extensive reviews of the literature, in order to confirm by different sources the validity of each transition. The terms "extension," "appropriation," "internalization" and "assimilation" are used by Nonaka (1990, 1991, 1994). The term "implicit learning" seemed to encompass the whole process of socialization, gathering of tacit and implicit stimuli, and articulating automatic knowledge (Spender, 1993) that are involved in the process of transition from individual-tacit knowledge to collective-tacit knowledge. The term is used by Reber (1993).

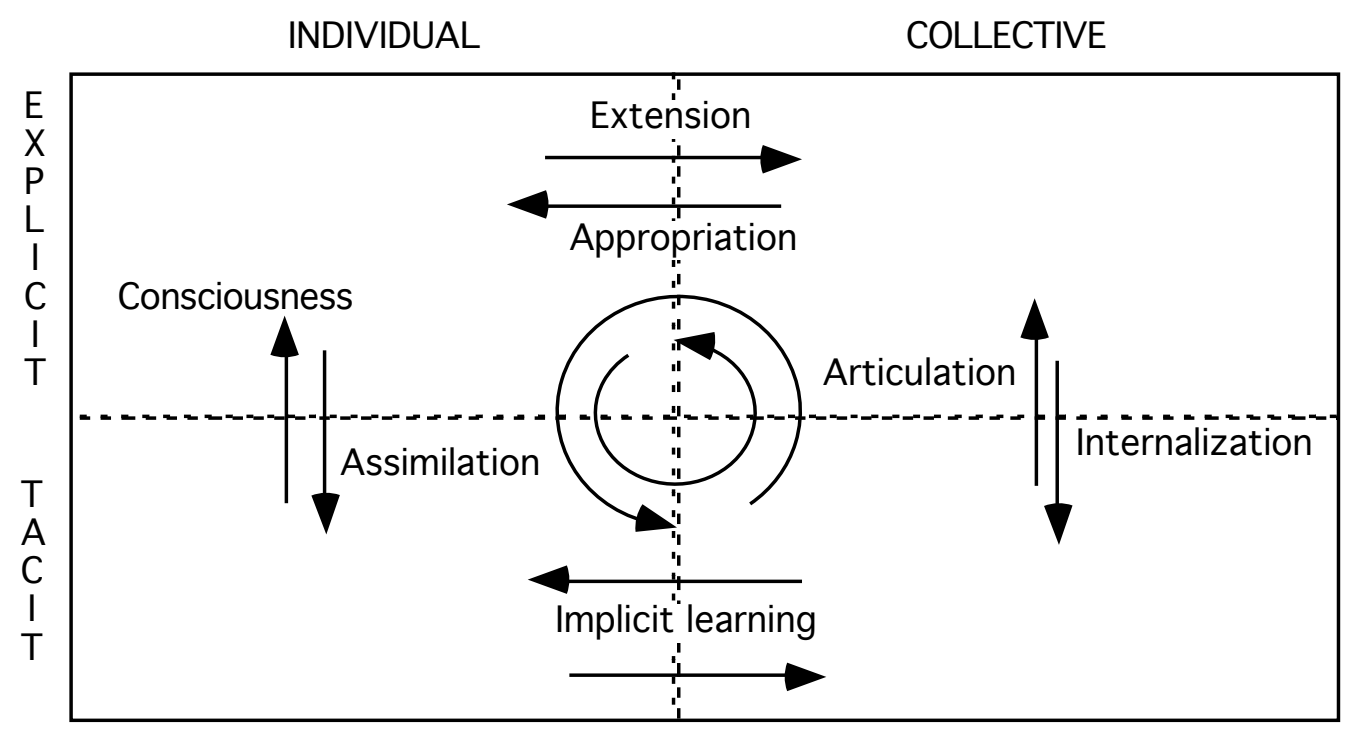

Fig. 3: An integrative framework to analyze transitions of knowledge types

The next step of the elaboration of the matrix was to compile all preceding elements in one single matrix. This enlarged and completed matrix (see Fig.4) contains both succinct descriptions of various types of knowledge within a specific knowledge type, and all of the above eight transitions (see next page). The matrix is presented here as a guideline to read the case descriptions. It was used accordingly in the data analysis process to verify the validity of findings with previous works. 


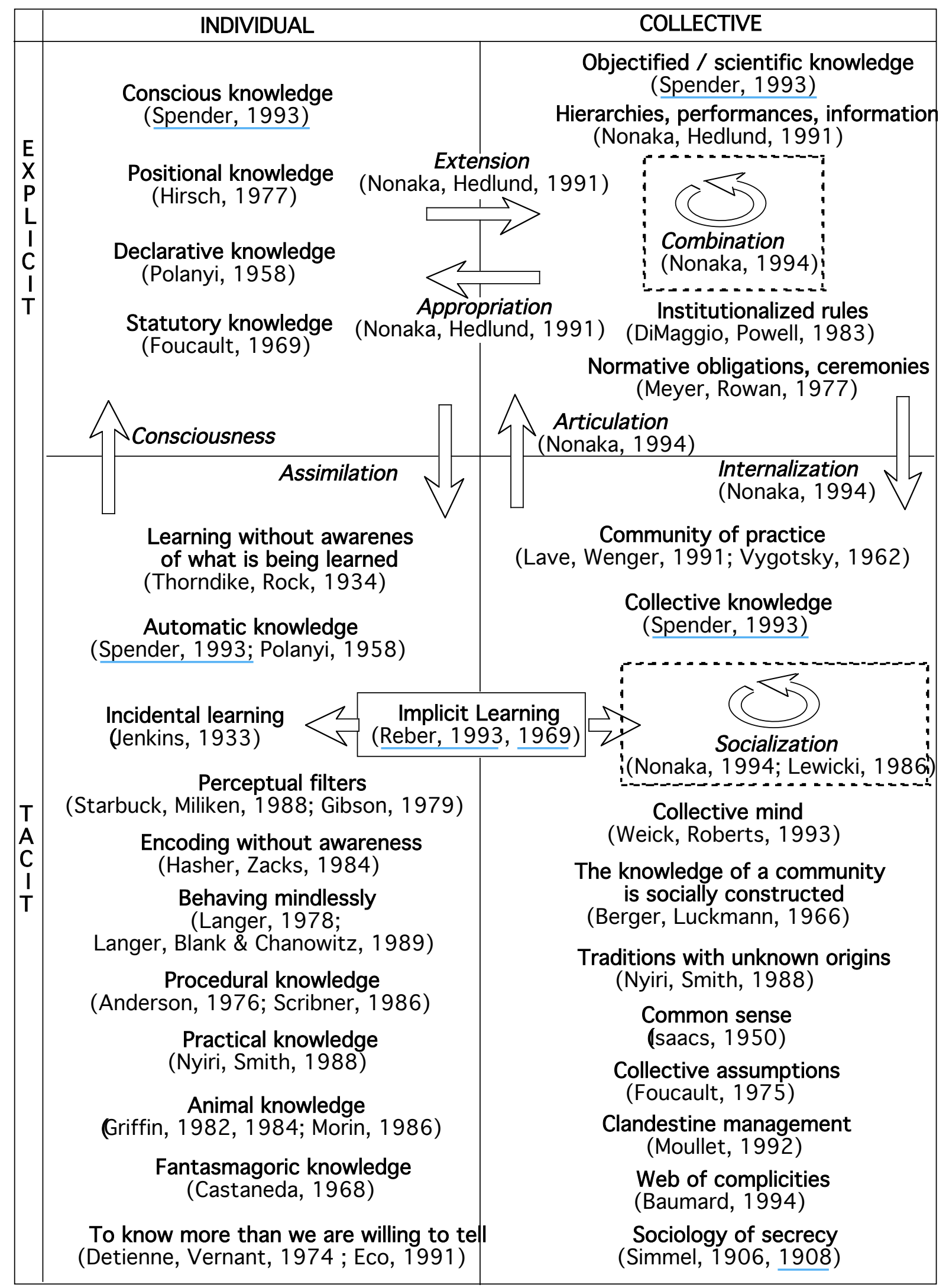

Fig 4: An augmented and completed matrix of knowledge modes 


\section{Case Studies}

\section{Indosuez: When Tacitness and Explicitness Collide}

In the late 1980s, Compagnie de Suez embarked "on a wild and opportunistic buying spree that caused the company to nearly triple in size [...] Since then, Suez's management has had difficulty digesting its acquisitions and managing its vast, disparate operations" (Liebowitz, 1993, p. 20). The decision resulted in a loss 1.87 billion French francs in 1992, downgrading the banking division from a AA to an A+ Standard \& Poor's rating, thanks to crushing losses from real estate loans in Paris. In this uncertain and mutable situation, Indosuez relied upon two major pillars: trading and merchant banking. In a bureaucratic and Cartesian environment (the French predilection to strategize first and execute later), the bank hastily acquired in February 1990 a team of "action-generators" (Starbuck, 1983) from Drexel Burnham Lambert to lead its structured finance operations. The ex-Drexelites soon made many of their own rules, and were subsequently frustrated by Parisian bureaucracy. A "transient, shifting, disconcerting and ambiguous situation" (Detienne, Vernant, Op. Cit.) arose rapidly. Indosuez management was "bewildered by the whole thing because decisions were being made in real time, and they were not used to that" (Liebowitz, 1993, p. 21). Problems were invented to justify the Drexel team acquisition. Jean Claude Gruffat, head of Indosuez US thus stated: "We really recruited them to achieve globalization." But it was clear that Indosuez "hired a crack trading team that wanted little to do with the bank's system, its politics, or its bureaucracy" (Liebowitz, Op. Cit.). Matters grew worse when Marc Schmitt, an 18-year veteran of Dresdner Bank, was recruited as head of international treasury operations in Paris, with oversight of the swaps group worldwide, including the small Drexelites team in New York. The rationale behind this new layer of management was that the president of the bank in Paris didn't want to be called any more to settle New York's problems. Schmitt had his own ideas about how to organize derivatives on a global scale and didn't go along at all with the Drexelites. Moreover, the idea of having the US swaps group managed directly by Paris was angrily challenged by the Drexelites. A first shift to tacit knowledge arose when Gruffat decided to maintain an informal "matrix" relationship with the Drexelites, approving increased credit lines, without being responsible for global trading, responsibility for which was still held in Paris. This "clandestine management" (Moullet, 1992) was a real learning experience for Gruffat.

But DeMonchaux, the head of the Drexelites, finally resigned and landed at Bear, Stearns \& Co., promptly raiding her former firm, Indosuez, and taking with her seven professionals. All of them took a week off to mull over their options. On his own initiative, Gruffat decided to gamble on luring back some of the group on their terms, "a politically risky move because it might have looked like he was challenging Schmitt and de Korsak," heads of the derivatives on a global scale in Paris: "My objective was to keep these people, and if there was a reporting problem, we had to find a way to keep them on board and provide them with a different environment" (Liebowitz, 1993, p. 25). Gruffat was more successful this time. He had learned to handle the mutability of the situation, without urging straightforward or conventional solutions. Indosuez US kept key elements of the Drexelites, who showed satisfaction with the tacit environment that had been provided to them. Outsiders were left with the 
impression that, in the beginning of events, the bank overmanaged the situation (Liebowitz, 1993, p. 26).

Further empirical research in Indosuez US showed traces of this learning in processes that were implemented by Gruffat in the bank after the events. When the French franc was vigorously attacked on the world markets in October 1993, Gruffat, facing a mutable and unpredictable situation, quickly started a "clandestine management" (Moullet, 1992) with key decision-makers in Paris and New York to cope successfully with the adversity. Permanent open phone lines were maintained during the shifting and disconcerting events between key influencers on the course of events. Similar oblique processes existed in the New York offices, between Gruffat and key elements of the trading room, ready to be activated in case of major mutation on the markets.

\section{Process analysis}

Evidence from our data unveils the chronology of events as follows (Fig. 5):

The Drexelites threaten to leave.

Some of them do.

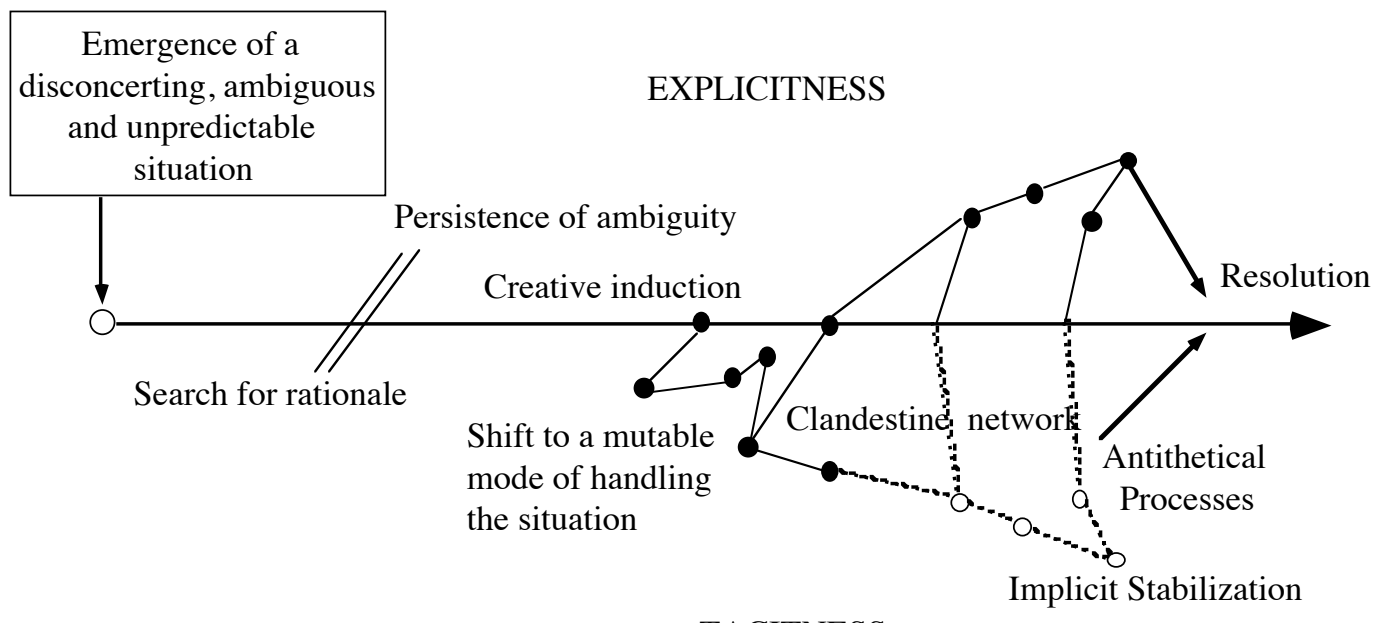

TACITNESS

Fig. 5: Struggling with ambiguity at Indosuez

When compiling data tables, movements around the matrix show three successive shifts (Fig. 6). First, Indosuez, with the purpose of deliberate learning, acquires the team ofDrexelites, without awareness of their tacit and individual dominant knowledge mode. The team integrates Indosuez, whose dominant knowledge mode is explicit and collective (second shift). Ambiguity arises. The situation reaches a state of critical crisis, and Indosuez management shifts to a tacit and collective mode of knowledge. Ambiguity is then channeled in this new approach of handling knowledge (see figure 6). 


\begin{tabular}{|c|c|c|}
\hline Explicit & Individual & Collective \\
\hline Tacit & $\begin{array}{c}\text { Derivative specialists from } \\
\text { Drexel-Lambert are hired } \\
\text { for their know-how. } \\
\text { Deliberate learning. }\end{array}$ & $\begin{array}{c}\text { The new work environment } \\
\text { is too explicit and ruled. } \\
\text { Danagement elaborates } \\
\text { a tacit matrix of } \\
\text { relationships. } \\
\text { Ambiguities are handled } \\
\text { collectively and tacitly. }\end{array}$ \\
\hline
\end{tabular}

Fig. 6: Dominant knowledge modes in Indosuez's struggle with ambiguity

\section{Qantas: Going Back to the Tacit Dimension}

In the Arizona desert, 900 aircraft await a slow rust deterioration in a plane graveyard. The world-wide airline industry experiences an over-capacity dilemma, as the economic recession continues. The industry has lost $\$ 12$ billions. Companies are seeking short-term returns to make their assets replacement and assets growth. If companies' policies are to maintain actual market standards, some experts strongly believe that some carriers won't be able to survive by themselves in such an environment. Most of them predict an increase in numbers of fusion-acquisitions and in the concentration of the whole sector. Such is the uncertain future airline companies have to deal with.

In the mid-1980s, Qantas management decided to put "more clarity on their future" and to consequently implement an environmental scanning system in the company. The two persons in charge of the project had gained their experience in the airline industry from working in the strategic planning formulation of the company. One of them had actually spent a part of her career in negotiating rights for opening routes. The other was sensitive to the broader strategic issues of globalization and long-term planning.

Nevertheless, the project failed. Reasons for failure were attributed both to management's attitude toward the system, and misunderstanding of the issues. The system was a computerized news-clipping service, integrated in the Executive Information System (EIS). At that time, the EIS was put through the internal network of the company and was accessible through keyboards. It was soon discovered that executives were not comfortable with using computers. The rate of utilization was extremely low. The scanning system was limited to short briefings on global economic (airline industry, global economy), market, technical and political environments. The system was designed solely for senior management. The number of personnel in charge of news-clipping was insufficient, as recalled by the implementers. Other sources say that "they didn't really know what to cut," confirming assumptions that noticing and making sense cannot be hermetically separated.

As soon as other managers learned that somebody was specifically in charge of making sense of what was going on in the industry, they started to disengage themselves from intensive search activities because "that was the responsibility of someone else." The executive infor- 
mation system was soon changed into touch-sensitive screens, with simplified menus. But it was put on a separate machine, provoking a social sign of distinction between those who had and those who did not have the "executive" information system. Perceptual filtering about the system was incrementally becoming predominant in managers' perceptions. So that managers might not appear to be priviliged in front of their colleagues, the system was simply rarely used, or used and then disregarded in informal conversations with colleagues.

Within a year, the initiative was abandoned and management returned to more informal and unsystematic channels. Roots of this failure can be found in the airline industry specifics. Operating an airline is firstly motivated by the maintenance of a culture of reliability (Weick, 1986). Airline industry culture is thus one of operations. Companies are proud of their history and publish brochures on the foundations of the company and the pioneering years. Stickers, pins and posters of early years' carriers are current purchases made by personnel who put them in their offices or their homes. The industry developed itself in a monopolistic, regulated, domestic environment. Marketing activities were seen as a fairly recent introduction in the industry. Partial deregulation and increased competition forced companies to be more financially oriented. The weight of finance in the airlines' strategies increased progressively during the past two decades. These three "cognitive oligopolies" (Baden-Fuller, Porac, Thomas, 1989) share the cognition of the environment. Senior Management is itself divided into top managers coming from the three different cognitive groups. Communication between people from marketing, operations and finance is difficult to achieve. Information richness is higher within the boundaries of the cognitive group where face-to-face work is more frequent. Communications between operations and marketing, for example, tend to follow more formal procedures.

The senior management is conscious that the evolution of the market (mixed regulation and deregulation, globalization and regionalization) calls for more precise, market-oriented schedule planning. The fact that a flight may be scheduled for a 9:00 a.m., rather than a 6:30 a.m. departure appears to be a marketing argument for segmenting the market. Scheduling softwares bear names such as "intelligent rescheduler systems" (IRS). Airline scheduling involves the treatment of a huge amount of data, with a zero-default imperative for passenger security. Problem-solving capability is at the center of intelligent rescheduling software: "IRS searches for ways to solve a problem, or set of problems, using the same process employed by operations staff, namely the immediate elimination of improbable solutions with the objective of avoiding or minimizing passenger disruption." Public opinion is rarely aware that airlines, until recent years, were scheduling their flights manually, within tight time constraints, on large boards where different color lines represented flights to be planned.

In the studied airline, consciousness of the issue fostered the interest for market-scheduling integration. The airline imported a scorecard methodology that "tracks the key elements of company's strategy, from continuous improvement and partnerships of teamwork and global scale" (Kaplan, Norton, 1992, p. 79). In an airline activity, schedule planning process is currently a dialectic between, on one side, requestors, and on the other side, contributors (see graph below). 


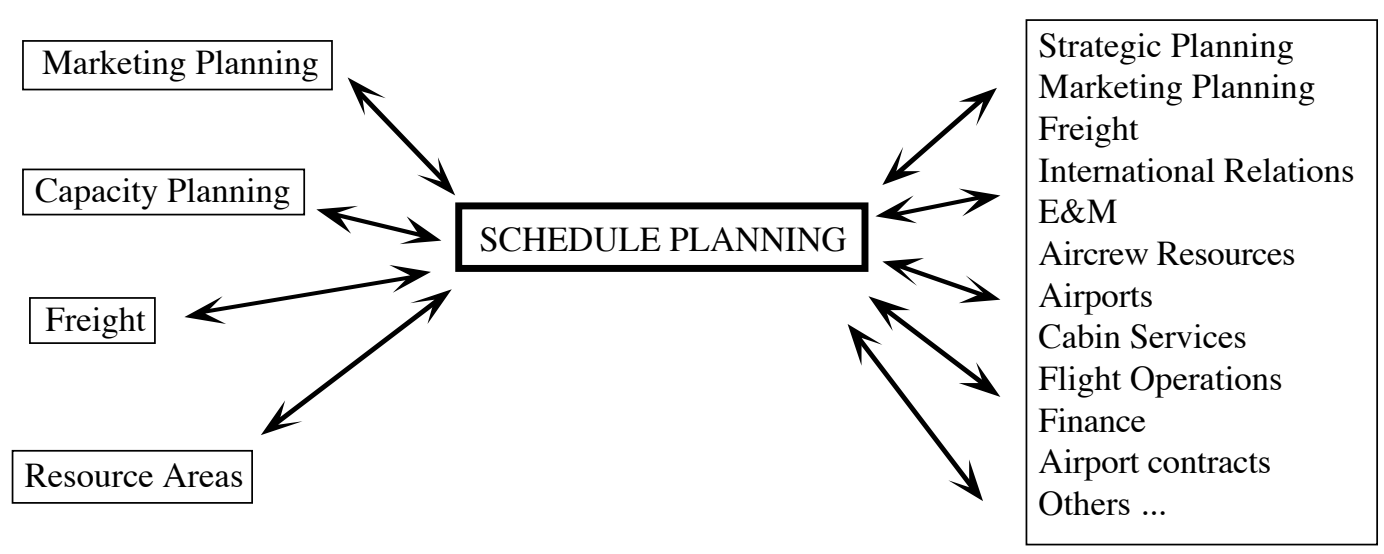

Fig. 7: Conventional scheduling process

In a context of permanent urgency (limited time frames), priorities are often given to schedule securing, passenger security and operations imperatives (minimizing passenger disruption). The operations cognitive group is then playing on its own territory. Voices of marketers hardly get expected feed-back. Scheduling is less market-oriented as it could be to give a competitive advantage to the company. Every request and contribution must be recorded and then ends up as a formal communication, even it started out as an informal phone call. Information is not shared, but exchanged, rationalizing the three cognitive groups and their territories.

The airline decided to put together a team of information systems engineers and strategic planners to define a prototype of a scheduling process that would put strategy - not control - at the center. Doing so, they decided to put together the noticing and the sensemaking of all different cognitive groups involved in this process. The principle of the prototype is to use advanced information technologies such as information sharing softwares to provide a framework wherein all participants can exchange their estimates freely and in real-time to achieve a strategy-oriented scheduling process. Requestors and contributors join together in an "electronic forum" respecting the industry procedures and allowing paracommunication. In other words, hard and soft data are exchanged in this shared formulation process, along with windows where personal estimates can be added to figures. This system opposed itself to "traditional measurement systems that have sprung from the finance function [...] that is traditional performance measurement systems that specify the particular actions they want employees to take and then measure to see whether the employees have in fact taken those actions. In that way, the systems try to control behavior. Such management systems fit with the engineering mentality of the Industrial Age" (Kaplan, Norton 1, 1992, p. 79). Thus, windows that have been added concern "political analysis, traffic rights and political implications, compatibility with strategy, alliance implications, passenger market analysis, freight market analysis and opportunities." Unconsciously, and maybe because the persons in charge of the strategy-based scheduling process were precisely those who failed in implementing environmental scanning four years ago, the new system includes broad knowledge.

1. Robert S. KAPLAN, David P. NORTON, Op. Cit., p 79. 


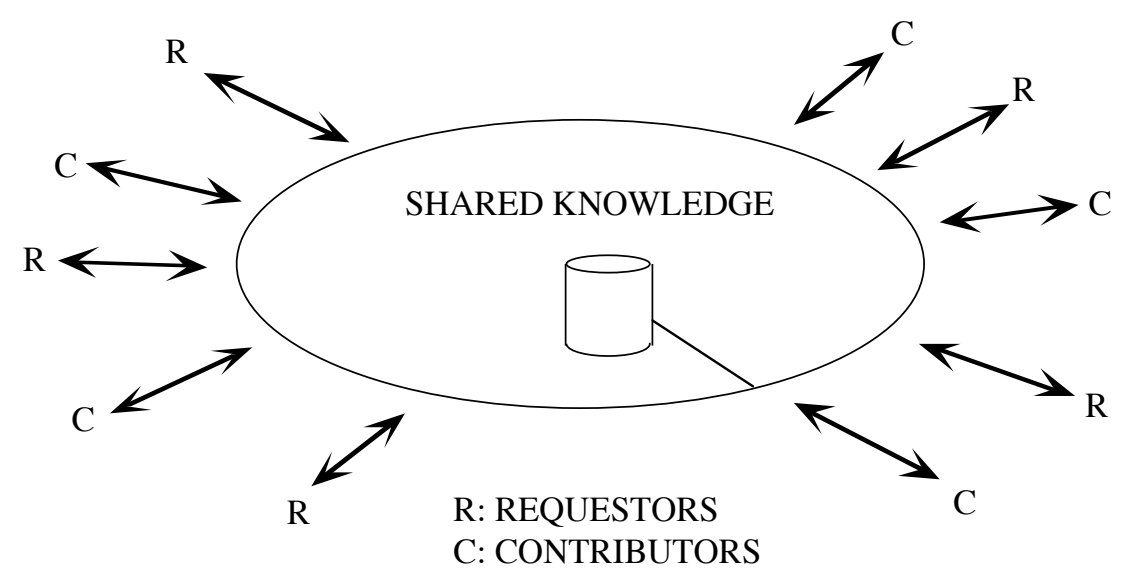

Fig. 8: The new scheduling process

The problem with information in organizations is that people "gather information and don't use it. Ask for more and ignore it. Make decisions first and look for the relevant information afterwards" (March, Shapira, 1982, p. 97). In that sense, the airline industry is fairly open. Managers often come from the same flying schools (pilots) or have been trained in specialized centers that are shared between several companies. In the Asian-Pacific country where this research was conducted, the Marketing Managers of six among the ten major competitors' subsidiaries come from the same school and know each other. It is not unusual for them to call a colleague to ask his or her feelings about a current industry trend.

"Analyzability" (Daft, Weick, 1984) of the airlines environment is usually perceived as high, even if tasks are complex. The environment is perceived as analyzable mostly because a great number of statistics are freely available. Governments are monthly publishing statistics about the airlines' loading, departures and arrivals - per country, and even sometimes per airport. These documents contain a short industry analysis, scheduled international air traffic to and from the country of origin, scheduled international passengers by operator, scheduled operator market shares, airline passenger capacity and utilization to and from the country. When such data are not available, insiders in foreign airports can easily get them. Other useful statistics can also be obtained from the Department of Immigration or from Customs about ethnic migrations, immigrations, movements of people per nationality. Another element that makes managers perceive their environment as "analyzable" is the extensive use of computerized reservation systems (CRSs). Reservation systems provide precise information on flight availability and allow companies to draw estimates by comparing national statistics concerning total passenger movements (customs) of all companies to their own data.

But direct observation tells another story. In order to gain knowledge in difficult situations, people "will adopt whatever behaviors and take whatever actions necessary to arrive at their goals" (Kaplan, Norton, 1992, p. 79). While management develops formal structures of knowledge circulation, people in the company continue to circulate knowledge within their cognitive groups (Marketing, Operations, Finance). In 1992, the company merged with Australian Airlines, and again tacit networks developed "below the organizational surface" (Moullet, 1992). Management understood the issue, and steps were taken to mix teams from Australian Airlines and Qantas. As a company's old boy sharply remark: "It's part of our history. Things get done this way, and I don't see why it shouldn't be right." 


\section{Process analysis}

Process analysis unfolds as follows (Fig. 9): As the deregulation provokes the emergence of an ambiguous situation concerning the organization's future, management decides to create an explicit and collective knowledge management system (the environmental scanning). The system is scarcely used, and progressively becomes a "social signature" rather than en effective tool to manage collective knowledge. Tacit networks develop, as a shift to a more mutable mode of handling knowledge emerges. Three tacit and collective networks of circulating and managing knowledge appear (marketing, finance and operations). Success in escaping ambiguity is better achieved through these networks (see Fig. 9).

\section{EXPLICITNESS}

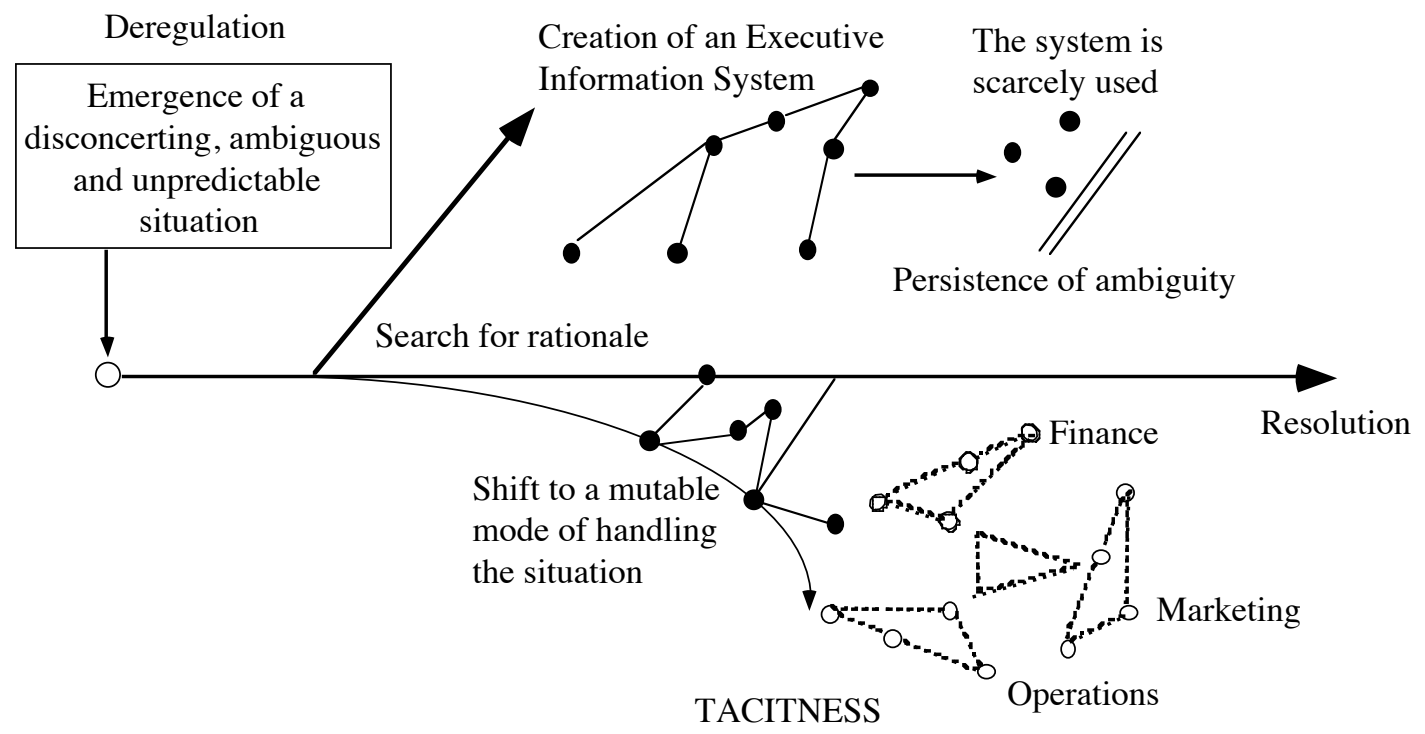

Fig. 9: Struggling with ambiguity at Qantas

When compiling data tables, movements around the matrix show three successive shifts (Fig. 10). In a first shift to a dominant mode of collective and explicit knowledge, management implements an environmental scanning system to try to make sense of ambiguous signals coming from its environment. The attempt fails, while many individuals avoid using the system and adopt a more tacit and individual mode of handling the situation (shift 2). As informal sensing techniques make their come-back, tacit networks, within the three different cognitive groups, re-emerge more precisely. Awareness that this tacit and collective knowledge mode is more efficient in ambiguity is largely shared in the company (shift 3 , see Fig. 10). 


\begin{tabular}{|c|c|c|}
\hline Explicit & Individual & Collective \\
\hline Tacit & $\begin{array}{c}\text { Informal sensing } \\
\text { techniques } \\
\text { make their come back }\end{array}$ & $\begin{array}{c}\text { Industry deregulation. } \\
\text { Pressure for an environmental } \\
\text { scanning system. } \\
\text { The system is designed } \\
\text { and implemented...(1988) }\end{array}$ \\
\hline and fails (1989) \\
$\begin{array}{c}\text { Tacit and collective } \\
\text { circulation of knowledge } \\
\text { (1992-1993) }\end{array}$
\end{tabular}

Fig. 10: Dominant knowledge modes in Indigo's struggle with ambiguity

\section{Pechiney: a Collective Tacit Agreement}

It is now widely accepted that organizations simultaneously generate processes that tend to change their characteristics and antithetical processes that affect these characteristics oppositely (Starbuck, 1988). Indosuez' case shows how "communal knowledge" (Spender, 1993) plays that role in organizations. Moreover, experience with ambiguity remains as a learning gain for the organization. Indosuez executives did maintain furtive and tacit procedures in their operational background. Complementary longitudinal research in Pechiney gives us the opportunity to test the permanence of these processes. Three major "disconcerting and ambiguous" situations, respectively in 1931, in the beginning 1950s, and in the period 1955-1960, were investigated on the basis of archival data (letters, internal memos, general and specialized press, agendas) and in-depth interviews with key witnesses (former CEOs and managers).

\section{Persistent rumors (1931-1932)}

In a letter from Gabriel Cordier to the president, on November 24, 1931, events unfold as follows: "Dear President, since yesterday, events precipitate: we have been hastily attacked on Lyon stock exchange. Attacks were based on following facts: $1^{\circ}-\mathrm{We}$ lost 600 millions in Russia, $2^{\circ}$-We lost 100 millions with the B.N.C., $3^{\circ}$ - We still have considerable amounts held in Italy, $4^{\circ}$ - To pay the succession rights (due on April 15, 1932), the Gillet family, completely drained of ready money, sells all its shares, $5^{\circ}$ - We harass our subsidiaries to such an extent that we appear as a disordered cavalry" (Pechiney, Historical Archives). Speculators spread rumors on the possibility of a bankruptcy. Contents of these rumors state that two administrators of the company are silent because of their recent suicides, and four others are said to have resigned. None of this being true, Pechiney brought the case to Court. Executives are in deep disarray. In an internal memo, a Senior Executive acknowledges: "We didn't deny and didn't publicly refute any rumors. [...] Such a communiqué would probably give consistence to noises." Ambiguity thus remains, and the share losses $25 \%$ in 10 days. A second conventional attempt to run down rumors is made. The President of the Executive Board writes a letter to shareholders to reassure them on the company finances. The mutable situation is finally handled by mutable means: executives build up clandestine and informal networks as to counter rumors on a local basis 
(stock exchange traders, bankers, key share holders, influential personalities of the business community). Adopting the same mutable form as the disturbing rumors, they act as antithetical processes.

\section{The $3 C^{3}$ process $(1950 s)$}

In the beginning of the 1950s, Vachet and Lamourdedieu visit Saint-Gobain glass factory, and come to the following conclusion: "Why don't we flow our aluminum like Saint Gobain is flowing its glass ?" (Lamourdedieu, 1990, p. 60). Easier said than done. Under the name of flowing process $3 \mathrm{C}^{3}$, a first sketch is drawn. Unsatisfactory. There is, however, an inventor under the name of Hazelett who successfully developed a similar process in Cleveland. The factory is soon visited by Lamourdedieu, but not much is learnt from unsuccessful trials that are presented that day. No viable technical answer is foreseen by Lamourdedieu. The choice is now to come back to Paris empty-handed, or to find an oblique way through the enigma. A dinner follows the visit to the factory at Lamourdedieu's hotel. Hazelett and four engineers are invited. "Reserving a seat for myself near the flower pot, I profited from the opportunity of getting rid of my whisky as my colleagues' attention was becoming more and more fuzzy" (Lamourdedieu, 1990, p. 83). The day after, Lamourdedieu is welcomed as the hero who resisted this memorable washed-down meal. The distrustful atmosphere has faded away, and Lamourdedieu comes back with valuable insight on the $3 \mathrm{C}^{3}$ process-to-be cooling system. With few improvements, the insights are adopted into the final flowing process. As Lamourdedieu later notices (Lamourdedieu, 1990), official and organizational memories retain another rationale for the discovery of the $3 \mathrm{C}^{3}$ process (Barrand, Gadeau, 1964).

\section{The Guinean Revolution (1955-1960)}

Pechiney's presence in Guinea follows the discovery, at 200 miles from Konakry, of important bauxite deposits. "The latter has a mediocre quality and has to be transformed on site, which is feasible thanks to the Koukouré river, that would provide energy" (Gignoux, 1955, p. 226). Such restricted geological conditions would later play a critical role, as there is no other technical solution that transforms the bauxite on site. The Koukouré river, however, is quite unpredictable, and can run at 1000 cubic meters in the rainy season, to 10 cubic meters in the dry season. There are no maps of Guinea, and Pechiney geologists are assigned to that task from 1942 to 1945 . Pechiney is trapped in a technical escalade of commitments, and the engineers' agenda will remain in the background of events until their final resolution. The geological and technical study is completed in 1951, and Pechiney management is "seduced by the outcome" (Marchandise, 1990, p. 84). In 1957, the aluminum production site is almost operational. The Company of Fria is founded. In September 1958, the government of Guinea declares its independence. A transient, shifting, disconcerting and ambiguous situation follows. "All happened just as if the whole operation would have escaped the hands of its initiators, leaving people 'on the ground' with the difficult task of conciliating the imperative of a balance exploitation, with the unpredictability of a Guinea administration and society in permanent revolution" (Larrue, 1990, p. 37). A tacit handling of the situation is initiated by Pierre Jouven, representing Paris management, Raoul de Vitry, President of the Company of Fria on site, and a few others. Raoul de Vitry obtains a tacit agreement from the new "Revolutionary" government of Guinea on the pursuit of the technical agenda. Pierre Jouven's role is critical. By comparing all memos and internal letters of the company during the period, Jouven's reporting style really stands apart. He carefully describes all the 
relationships and connections of people he meets, using a rich, vivid, and detailed style. Every single personality is analyzed: "This person was obliging, but I noticed an embarrassed meddling," "the two Parliamentarians were most active in our discussions. They congratulated our position and our project...." The gap between Jouven's soft knowledge and technical reports regarding the industrial agenda is tremendous. Pechiney avoided the worst in the Guinea case, and kept the aluminum production running.

\section{Process analysis}

Process analysis on the Guinean case unfolds as follows (Fig. 11): a disconcerting, ambiguous and unpredictable situation emerges when the Guinean government decides to nationalize plants and energy sources. Engineers stick to the technical agenda and try to tolerate the ambiguity of the situation. But ambiguity persists, and both management from Paris headquarters and Konakry decide to take action. Pierre Jouven, along with others, plays the role of mediator. Pierre Jouven's rich understanding serves as a basis to develop a tacit understanding between different parties. A tacit collective agreement is finally reached (see figure below).

\section{EXPLICITNESS}

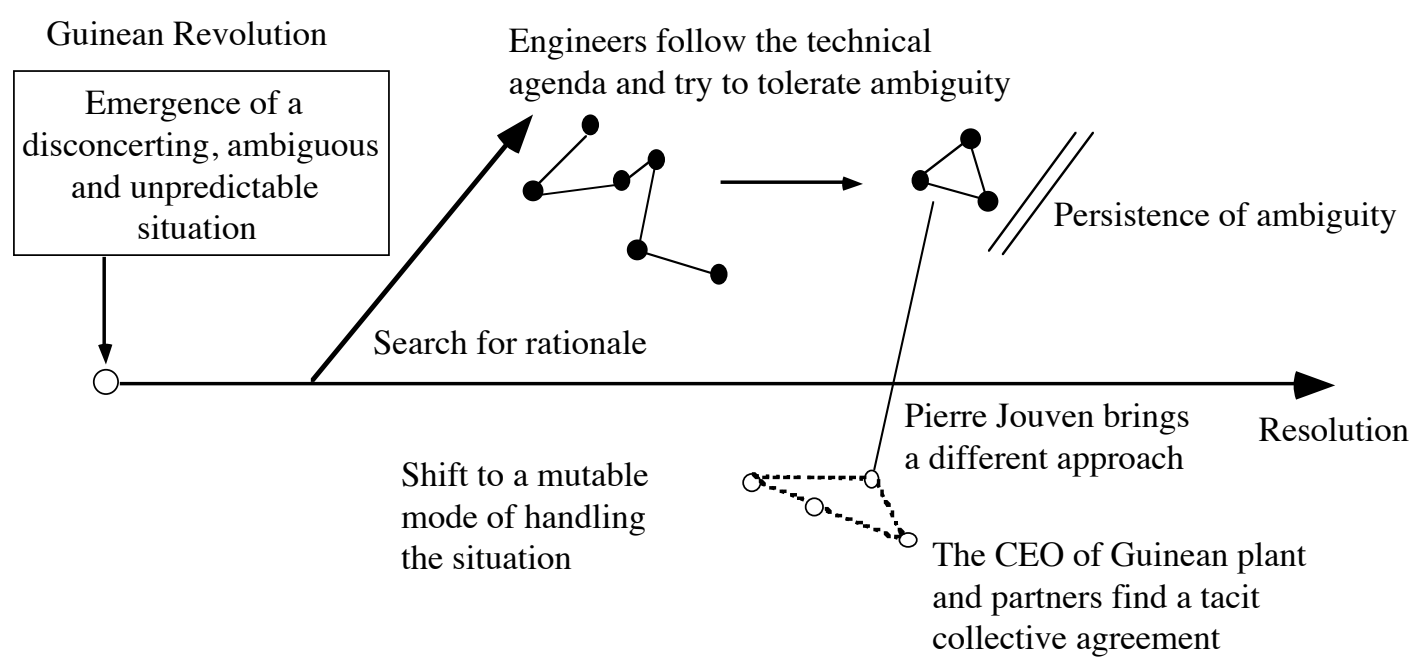

TACITNESS

Fig. 11: Struggling with ambiguity at Pechiney (Guinea)

When compiling data tables, movements around the matrix show three successive shifts (Fig. 12). From 1930 to 1951, the dominant mode of knowledge is one of engineers searching for energy sources and technical possibilities. When the technical agenda is set up, and first operations started (1952-1958), we are still in a collective and explicit knowledge mode. With the Guinean revolution, a new situation arises where everything, the worst included, become possible. Position of different parties become ambiguous, although there is an effort to clarify intentions and commitments. Here, the tacit and individual knowledge of a few key managers of Pechiney, including Pierre Jouven, plays a major role in improving understanding of the situation and setting dialogue. Managers learn implicitly the way for dealing with this new ambiguous situation. A final shift to a collective and tacit knowledge 
mode occurs, as a tacit agreement on the continuity of Pechiney's operations in Guinea is reached (see Fig. 12).

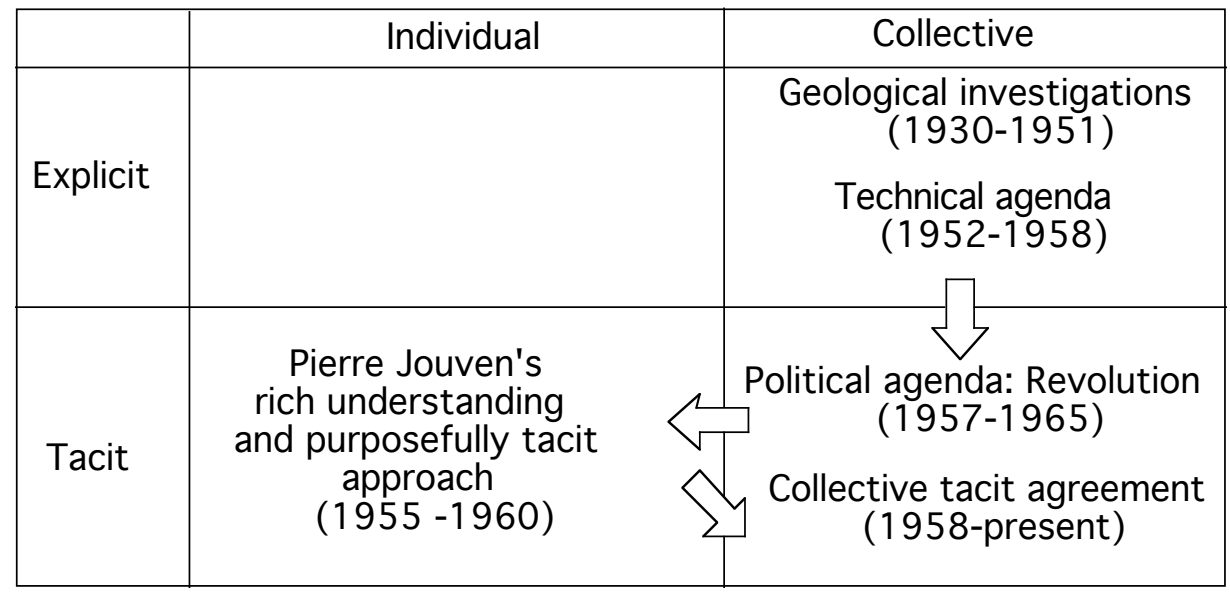

Fig. 12: Dominant knowledge modes in Pechiney's struggle with ambiguity

\section{Indigo: Thriving in the Fog}

Founded in 1981, Indigo, Inc. is a small publishing company specializing in the editing and printing of confidential letters. Publications include Africa Energy and Mining, The Indian Ocean Newsletter, East Asian Affairs, Maghreb Confidential. Access to publications is exclusively through confidential and direct subscriptions. Clients include governments and multinationals on five continents. Indigo knows a rapid growth of its activities and its publications are highly regarded by executives and government officials. Indigo's case was selected on the assumption that accessing sensitive information requires peculiar abilities to handle disconcerting and ambiguous situations in order to make sense of and unveil hidden realities to readers. Attention was given to the work of the small staff of twelve involved in producing the letters and getting access to valuable insights.

Indigo's current mode of operations is constantly moving from "an exhaustive and rational approach of events and a more intuitive approach" (CEO, interview). A first phase - made the shortest - consists in reading what is publicly known on the event: "It gives us directions to search for the unpublished. We know the editorial habits, ideologies, and policies of the press we scan. For example, in certain African countries, ethnical issues are never addressed directly. Instead, to suggest the role played by an ethnical group, journalists are mentioning the villages involved in the event. The African reader is aware of which ethnical group is involved." Indigo editors never handle facts directly: "Results are lying in wait," the editor says. Thus, direct observation reveals "a state of vigilant premeditation, of continuous concentration on activity that is in progress" (Detienne, Vernant, 1978, p. 14). As Indigo founder put it: "Our job is to read the implicit like an open book, to navigate in the unsaid, eventually preparing the ground for the unsaid to be unveiled." Unfortunately, the implicit is never revealed in any objective forms. As the CEO continues: "We maneuver in a tacit field, eventually reaching steadily a grip that we won't release until the situation makes sense." All redactors are boundary-spanners (Daft, Weick, 1984). Problems are tackled at their source, involving intense traveling: "We constantly navigate backward and forward from the back- 
ground to the foreground of knowledge" (Founder, interview). When a French Deputy is said to be on official visit in Africa (foreground), redactors search for informal and tacit links of this Deputy with a corporation that might be involved in a contract negotiation in the area (background). "We imagine a rationale that would fit the events, and keep the succession of events in memory. And we wait for the illumination, helping it out by accessing informed sources." Thus, knowledge is never exhaustively formalized until final publication: "We incubate," as the CEO put it. That was Indigo's routine until the very day events did not turn out as expected.

That day, one of the editors discovers the picture of a new ambassador of Malte in Seychelles: "I found the whole thing awkward. Why is there a Malte Order in Seychelles ?." Then starts the process of navigating between the implicit and the explicit: "We avoid beeing too straightforward in our understanding of events." The first search is disconcerting. Apparent ambiguity unveils nothing more than further ambiguity. Nothing sounds neither rational nor sustainable for publication. The enigma unfolds as follows: "An ambassador who was not an ambassador, did and didn't own hotels, had and hadn't a questionable past ...." Creative induction is finally the way out. Accurate meaning is soon given to the disperse and ambiguous events. Editors deliberately make their search highly mutable, letting their investigation be even more twisted that the reality it has to handle. "There were no awaited immediate returns. The only thing awaited was the precise moment when an interesting line to pull would show up," the editor recalls.

The respondent's conclusion on the Seychelles case is the following: "We are dependent on tight resources. With artisanal means, and at our individual scale, we managed to achieve numerous tasks that foster envy in larger and more organized institutions. I believe that we are consequently dependent on our ability to foresee the advent of such situations, and to be aware that we only stand at the premises of what would be the outcome."

\section{Process analysis}

Chronology of events unfolded as follows (Fig 13): with a predilection to taciteness in is mode of operations, Maurice Botbol undertakes the routine of investigating the environment for rare knowledge for his newsletters. Through serendipity, he discovers unusual links between a few elements of knowledge. Through creative induction, he builds a scenario that makes sense on the basis of the tacit knowledge he possesses of various elements involved. A disconcerting, ambiguous and unpredictable situation emerges in the Seychelles case, as events go faster that he expected, unveiling connections he did not suspect. Ambiguity persists, and Botbol tries to imagine a path that would fit the situation. With the help of others, and trying to articulate all their knowledge, Indigo members seize steadily identified grips, and make explicit what they believe to be an accurate understanding of the situation. 


\section{EXPLICITNESS}

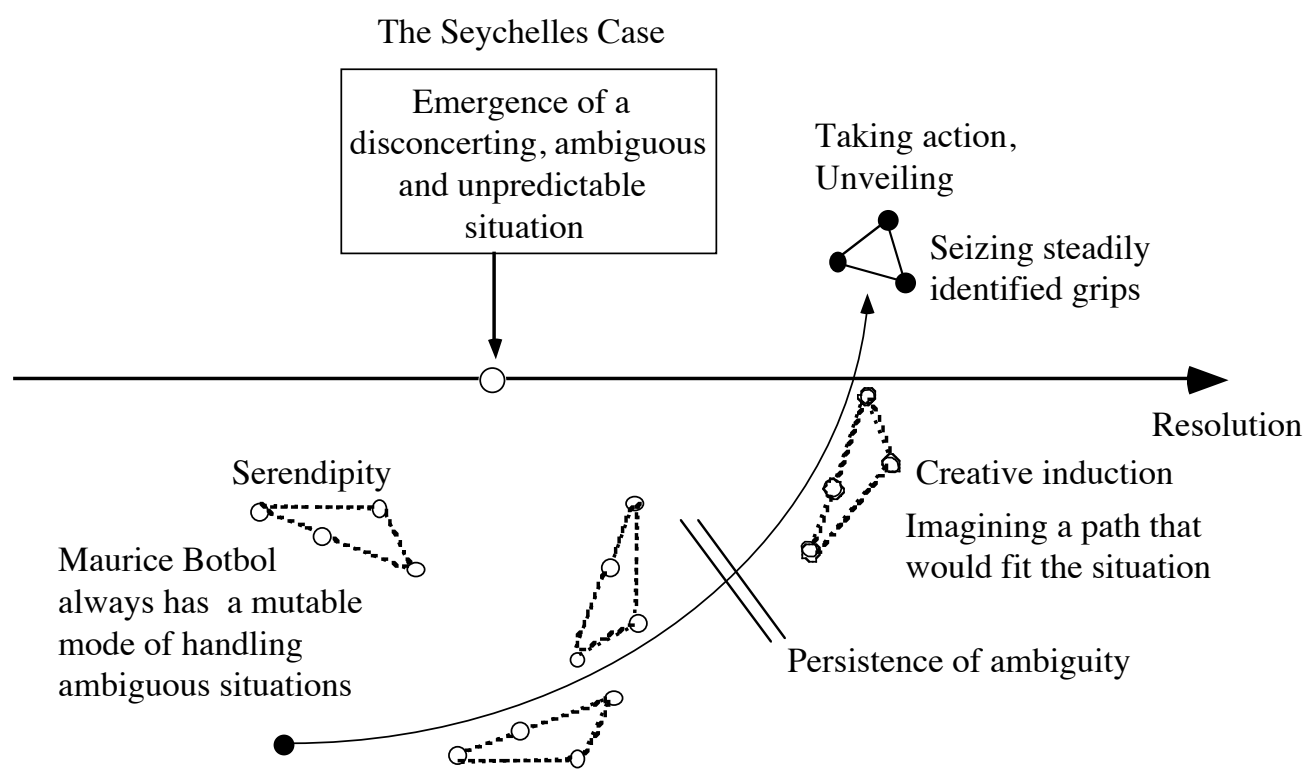

TACITNESS

Fig.13: Struggling with ambiguity at Indigo

When compiling data tables, movements around the matrix show three successive shifts (Fig. 14). In a tacit and individual dominant knowledge mode, Maurice Botbol, through means of serendipity and creative induction detects incongruities in a sequence of events (Seychelles case). He then tries to make sense of the contradictory stimuli, but ambiguity persists. Shifting to collective and tacit knowledge, Indigo "navigates" in ambiguity by socializing and exchanging undetermined and mutable elements of knowledge. Indigo finally has to formulate an explicit vision of the events for the newsletter. The transition is difficult.

\begin{tabular}{|l|c|c|}
\hline Explicit & Individual & Collective \\
\hline Tacit & $\begin{array}{c}\text { Maurice Botbol's reflective } \\
\text { practice on his tacit } \\
\text { approach to his environment }\end{array}$ & $\begin{array}{c}\text { The Seychelles case } \\
\text { is made public. } \\
\text { The team becomes aware } \\
\text { of the difficulty of transition. }\end{array}$ \\
\hline $\begin{array}{c}\text { The team works } \\
\text { the same way. }\end{array}$ \\
Investigators "navigate" \\
collectively in ambiguity.
\end{tabular}

Fig. 14: Dominant knowledge modes in Indigo's struggle with ambiguity 


\section{Findings}

We first discover some cross-cases and general observations. When trying to escape ambiguity, senior managers often neglect local and conjectural knowledge in the first place (Qantas, Indosuez, Pechiney). This neglect seems stronger in large firms (Qantas, Pechiney). When trying to escape ambiguity, senior managers tend to over-manage (Pechiney, Qantas, Indosuez).

Success in escaping ambiguity depends on abilities to switch promptly between appropriate modes of knowledge. However, these shifts are "painful." They require organizational flexibility, and a certain reflective thinking on the organizational knowledge.

Tacit knowledge plays a critical role in developing a rich understanding of ambiguous situations. Organizations (Indigo) or people (Maurice Botbol, Jean Claude Gruffat, Pierre Jouven) that develop specific skills in handling tacit knowledge show better efficiency in handling such situations, and thus, tacit knowledge, when managed adequately, can constitute a crucial competitive advantage for those organizations or people who develop implicit learning skills. Accordingly, tacitness (unsaid, incommunicable, transitory, mutable knowledge) leaves more margin for maneuvers. Thus, Indigo's case stands apart in our four cases. Indigo's managers tend to "create fog to thrive in the fog." They enact ambiguity to exploit it, as rhetorists elaborate ambiguity to develop an inquisive spirit.

\section{Conclusion}

Methods to enhance and systematize a knowledge management that would give to tacit knowledge its deserved place in management has yet to be revealed. However, results show that organizations often neglect the tacit dimension of knowledge both in their day-by-day operations and in their long-term thinking.

Large organizations, for they are more institutionalized, hierarchical and resistant to change, show lesser performances in developing competitive advantage from tacit knowledge. A smaller organization like Indigo, which is more adhocratic and flexible, show better performances in both struggling with ambiguity and adapting to ambiguous situations. Results thus suggest that downsizing may be a path to a better management of knowledge.

More generally, research results show that there is more into knowledge than its conventional and positivistic perception as knowledge-as-information. The study of organizational knowledge creation not only differently enlightens many traditional organizational issues (organizational learning, crisis management), it also open the doors for a new reading of organizations, no longer as decision-making ensembles, but as interrelated dynamics of knowledge and organizational issues. 


\section{References}

Alesina, Alberto, Cukierman, Alex, (1990, November), "The politics of ambiguity," The Quarterly Journal of Economics ,v. 105 , pp. 829-850.

Alvesson, Mats, (1993, November), "Organizations as rhetoric: Knowledge-intensive firms and the struggle with ambiguity," Journal of Management Studies, Vol: 30, Iss: 6, pp. 997-1015.

Anderson, J.R. (1976), Language, memory and thought, Hillsdale, NJ: Erlbaum.

Baars, B.J., (1986), The cognitive revolution in psychology, New York: Guilford.

Barrand P., Gadeau R. (et al.), (1964), L'Aluminium, Two Volumes, Paris: Eyrolles.

Bartlett, F.C., (1954), Remembering: A Study in Experimental and Social Psychology, Cambridge, MA: Harvard University Press.

Baumard, Ph., (1992, April), "Concertation et culture collective de l'information," Annales des Mines, (Réalités Industrielles), Paris: Eska.

Baumard, Ph., (1994a, March), "Oblique Knowledge: The Clandestine Work of Organizations," Cahiers de Recherche DMSP $\mathrm{n}^{\circ}$ 228, Paris: Université de Paris-Dauphine.

Baumard, Ph., (1994b) "How do corporations notice and make sense ? The emergence of intelligence-intensive corporate strategies," The International Journal of Intelligence and Counterintelligence, Vol. 7, No. 2, New York: Intel Publishing.

Baumard, Ph., (1991), Stratégie et surveillance des environnements concurrentiels, Paris: Masson.

Berger, Peter L., Luckmann, Thomas, (1966), The Social Construction of Reality, Garden City, NY: Doubleday.

Berry, Michel, (Juin 1983), Une technologie invisiblee? L'impact des instruments de gestion sur l'évolution des systèmes humains, Paris: Centre de Recherche en Gestion de l'Ecole Polytechnique.

Bird, Allan, (1994), "Careers as repositories of Knowledge: A New Perspective on Boundaryless Careers," New York University, Working Paper Mgmt
\#94:9, March 1994, forthcoming in the Journal of Organizational Behavior.

Brun, Wibecke., Teigen, Karl Halvor, (1988, June), "Verbal probabilities: ambiguous, context-dependent, or both?," Organizational Behavior and Human Decision Processes, v. 41, pp.390404.

Castaneda, Carlos, (1968), The teachings of Don Juan: a Yaqui way of knowledge, Los Angeles: University of California Press.

Covino, William A., (1988), The Art of Wondering: A Revisionist Return to the History of Rhetoric, Portsmouth, NH: Boynton/Cook Publishers.

Crozier, Michel, Hedberg, E. (1977), L'acteur et le système, Paris: Editions du Seuil.

Curley, Shawn P.; Yates, J. Frank, Abrams, Richard A., (1986, October), "Psychological sources of ambiguity avoidance," Organizatonal Behavior and Human Decision Processes, v. 38, pp. 230-256.

Cyert, Richard M., March, James G., (1963), A behavioral theory of the firm, Englewood Cliffs, NJ: Prentice Hall.

Dacey, Raymond, (1976), "The role of ambiguity in the manipulation of voters," Norman: Center for Economic and Management Research, College of Business Administration, Working Paper Series, $18 \mathrm{p}$.

Daft, Richard L., Weick, Karl E., (1984), "Toward a Model of Organizations as Interpretation Sys-tems," Academy of Management Review, Vol. 9, No. 2, pp. 284-295.

de Groot, A.D., (1946), Het Denken van den Schaker, Amsterdam: N. H. Utig. Mij.

de Groot, A.D., (1965), Thought and Choice in Chess, The Hague: Mouton.

de Groot, A.D., (1966), "Perception and memory versus thinking" in B. Kleinmuntz (ed.), Problem Solving, New York: Wiley.

Détienne, Marcel, Vernant Jean Pierre, (1974), Les ruses de l'intelligence: La mètis des Grecs, Paris: Flammarion. 
DiMaggio, Paul J., Powell, Walter W., (1983), "The iron cage revisited: Institutional isomorphism and collective rationality in organizational fields," American Sociological Review, Vol. 48, pp. 147160.

Eco, Umberto, (1992), Les limites de l'interprétation, Paris: Grasset.

Eisenhardt, K.M., Bourgeois, L.J., (1988), "Politics of Strategic Decision Making in HighVelocity Environments: Toward a Midrange Theory," Academy of Management Journal, Vol. 31, No. 4, pp. 737-770.

Eisenhart, Kathleen M., (1989), "Building Theories from Case Study Research," Academy of Management Review, Vol. 14, $\mathrm{N}^{\circ} .4$, pp. 532-550.

Ekstedt, Eskil, (1989), "Knowledge Renewal and Knowledge Companies," Research Report No. 22, Uppsala, Sweden: Uppsala Papers in Economic History, Uppsala University.

Eriksen, C.W., (1958), "Unconscious Processes," in M.R. Jones (Ed.), Nebraska Symposium on Motivation, Lincoln: University of Nebraska Press, pp. 169-278.

Fischhoff, Baruch, (1982), "For Those Condemned to Study the Past: Heuristics and Biases in Hindsight" in Daniel Kahneman, Amos Tversky, Paul Slovic (Eds.), Judgement Under Uncertainty: Heuristics and Biases, Cambridge: Cambridge University Press, p. 343.

Foucault, Michel, (1969), L'Archeologie du savoir, Paris: Gallimard.

Foucault, Michel, (1975), Surveiller et punir: naissance de la prison, Paris: Gallimard.

Geertz, Clifford, (1983), Local knowledge: Further essays in interpretive anthropology, New York: Basic Books.

Gibson, E.J., (1969), Perceptual Learning and Development, New York: AppletonCentury-Crofts.

Gibson, J.J., (1979), The ecological approach to visual perception, Boston: Houghton Mifflin.

Gignoux, Charles J., (1955), Histoire d'une entreprise française, Paris: Hachette.

Glaser, Barney G., Strauss, Anselm L., (1967), The discovery of grounded theory: strategies for qualitative research, Chicago: Aldine Pub. Co.

Goleman, Daniel, (1985), Vital Lies, Simple Truths: The Psychology of Self-Deception, New York: Simon \& Schuster.

Gordon, P.C. and Holoyak , K..J., (1983), "Implicit Learning and Generalization of the 'Mere Exposure' Effect," Journal of Personality and Social Psychology, 45, pp. 492-500.

Gray B., Bougon M., Donnellon A., (1985), "Organizations as Constructions and Deconstructions of Meaning," Journal of Management, Vol. 11, No 2, pp. 185-211.

Greenspoon, J. (1955), "The reinforcing effects of two spoken sounds on the frequency of two responses," American Journal of Psychology, 68, pp. 409-416.

Gregory, Richard L., (1988), "Ambiguities of sense and non-sense." Perception, Vol. 17, No. 4, pp. 423-428.Griffin, D.R., (1984), Animal Thinking, Cambridge, MA: Harvard University Press.

Griffin, D.R., (1982), Animal Mind, Human Mind, New York: Springer-Verlag.

Hasher, L. and Chromiak, W. (1977), "The processing of frequency information: An automatic mechanism?," Journal of Verbal Learning and Verbal Behavior, 16, pp. 173-184.

Hasher, L. and Zacks, R.T. (1984), "Automatic processing of fundamental information," American Psychologist, 48, pp. 13721388.

Hedberg, Bo, (1981), "How organizations learn and unlearn," in P. Nystrom, W. Starbuck, (Eds), Handbook of organizational design, New York: Oxford University Press, pp. 1-27.

Hedberg, Bo; Nystrom, Paul C.; Starbuck, William H., (1976), "Camping on Seesaws: Prescriptions for a Self-Designing Organiza-tion," Administrative Scien-ce Quaterly, volume 21 (March), pp.4165.

Herbig K.L., Daniel D.C., (1983), "Deception in Military Affairs: Propositions for Historical Analysis," in Wilhelm Agrell, Bo Huldt, Clio goes spying: Eight Essays on the History of Intelligence, Malmö: Scandinavian University Books,. 
Herzberg, Frederick, (1987), "Innovation: Where Is the Relish? ," Journal of Creative Beha-vior, Vol. 21, No 3, pp. 179-192.

Hirsch, Fred, (1977), Social limits to growth, London: Routledge \& Kegan Paul.

Imel, Susan (1992), "Reflective Practice in Adult Education," ERIC Digest No. 122, ERIC Clearinghouse on Adult, Career and Vocational Education, Columbus, Ohio, sponsored by the Office of Educational Research and Improvement, Washington, DC, Report No. EDO-CE-92-122.

Isaacs, Nathan, (1950), The Foundations of Common Sense, New York: Roy Publishers.

Jenkins, J.G. (1933), "Instruction as a factor of 'incidental' learning," American Journal of Psychology, Vol. 45 , pp. 471-477.

Johnson-Laird, (1983), Mental Models, Cambridge: Cambridge University Press.

Kaplan, Robert S. and Norton, David P. , (1992), "The Balanced Scorecard - Measures That Drive Performance," Harvard Business Review, pp. 71-79.

Kerr, Marjory Ruth, (1992), An analysis and application of tacit knowledge to managerial selection, Ottawa: National Library of Canada.

Kottkamp, R.B., (February 1990), "Means for Facilitating Reflection," Education and Urban Society, Vol. 22, no. 2, pp. 182203.

Lamourdedieu Marcel, (1990), "Carnet de Route," Cahiers d'Histoire de l'Aluminium, No 6, summer 1990, Paris: Institut pour l'Histoire de l'Aluminium, pp. 60-84.

Langer E., Blank A., Chanowitz B., (1978), "The mindlessness of ostensibly thoughtful action: the role of 'placebic' information in interpersonal interaction," Journal of Personality and Social Psychology, $\mathrm{N}^{\circ} 36$, pp. 635-642.

Langer, E., (1978), "Rethinking the role of thought in social interaction," in J. Harvey, W. Ickes, R. Kidd (Eds.), New directions in attribution theory, Vol. II, Hillsdale, NJ: Erlbaum, pp. 35-58.

Larrue, Jacques, (1990), "Fria en Guinée: Des aspects humains d'une industrialisation différente,"Cahiers d'Histoire de l'Aluminium, No. 7, Paris: Institut pour l'Histoire de l'Aluminium, pp. 37-48.
Lasley, T., (1989, March-April), "Editorial," Journal of Teacher Education, Vol. 40, no. 2.

Lave J., Wenger E., (1991), Situated learning: legitimate peripheral participation, New York: Cambridge Unvier, pp.98100.

Lewicki, P., (1986), Nonconscious social information processing, New York: Academic Press.

Liebowitz, Michael, (1993), "The Identity Crisis at Indosuez US," Investment Dealers' Digest, Vol. 59, No. 16, pp. 20-26.

Lincoln, Yvonna S., Guba, Egon G., (1985), Naturalistic Inquiry, Beverly Hills, CA: Sage.

March, James G. and Cyert, Richard M., (1963), A behavioral theory of the firm, Englewood Cliffs, NJ: Prentice Hall.

March, James G., (1978), "Bounded Rationality, Ambiguity, and the Engineering of Choice," Bell Journal of Economics, pp. 33-57.

March, James G. and Shapira, Zur, (1982), "Behavioral Decision Theory and Organizational Decision Theory," in G. Ungson, D. Braunstein (Eds.), Decision Making, Boston:Kent, p.97.

March, James G. and Olsen, Johan P. (Eds), (1976), Ambiguity and choice in organizations, Bergen: Universitets-forlaget.

Marchandise, Jacques, (1990), "Histoire de Fria," Cahiers d'Histoire de l'Aluminium, No. 7, Paris: Institut pour l'Histoire de l'Aluminium.

Marquardt, Michael J; Engel, Dean W., (1993, May), "HRD Competencies in a shrinking world," Training \& Development, Vol. 47, Iss. 5, pp. 59-65.

Meyer, John W., Rowan, Brian, (1977), "Institutionalized Organizations: Formal Structure as Myth and Ceremony," American Journal of Sociology, Volume 83, No. 2, pp. 340363.

Miles, Matthew B., Huberman, A. Michael, (1984), Qualitative Data Analysis, Beverly Hills, CA: Sage Publications.

Morin, Edgard, (1977), La Méthode I: La Nature de la Nature, Paris: Editions du Seuil.

Morin, Edgard, (1980), La Méthode II: La Vie de la Vie, Paris: Editions du Seuil. 
Morin, Edgard, (1986), La Méthode III: La Connaissance de la Connaissance, Paris: Editions du Seuil.

Moullet, Michel (1992), Le Management Clandestin, Paris: Inter-Editions.

Newell, A., Simon H.A., (1972), Human Problem Solving, Englewood Cliffs, NJ:Prentice Hall.

Nisbett, R.E., Ross L., (1980), Human inferences: Strategies and shortcomings of social judgement, Englewood Cliffs, NJ: Prentice Hall.

Nisbett, R.E., Wilson, T.D., (1977), "Telling more than we know: Verbal reports on mental processes," Psychological Review, Vol. 84, pp. 231-259.

Nonaka, Ikujiro, (1988), "Creating organizational order out of chaos: Self-renewal in Japanese firms," California Management Review, v. 30 (Spring '88), pp. 5773.

Nonaka, Ikujiro, (1990), "Managing innovation as a knowledge ceating process," paper presented at New York University, Stern School of Business, Intenational Business Colloqium.

Nonaka, Ikujiro, (1991), "The knowledge-creating company," Harvard Business Review, v. 69 (Nov.-Dec. ), pp. 96-104

Nonaka, Ikujiro, (1993), "A Management Theory of Organizational Knowledge Creation," Research Paper (draft), unpublished, 58 pages (including ref.).

Nonaka, Ikujiro, (1994), "A Dynamic Theory of Organizational Knowledge Creation," Organization Science, Vol. 5, No. 1, February, pp. 14-37.

Nonaka, Ikujiro, Hedlund, Gunar (1991b), "Models of Knowledge Management in the West and Japan," Institute of International Business at the Stockholm School of Economics, Research Paper 9/91.

Nyíri, János Kristóf, Smith, Barry (Eds.), (1988), Practical Knowledge: Outlines of a Theory of Traditions and Skills, New York: Croom Helm.

Osterman, K. F., (1990, February), "Reflective Practice: A New Agenda for Education," Education and Urban Society, Vol. 22, no. 2, pp. 133-152.

Peters, J., (1991), "Strategies for Reflective Practice" in Brockett, R. (Ed.), Professional
Development for Educators of Adults, San Francisco: Jossey-Bass.

Piaget, J., (1974), Recherches sur la contradiction, Paris: Presses Universitaires de France.

Polanyi, Michael (1958), Personal knowledge: Toward a post-critical philosophy, Chicago: University of Chicago Press.

Polanyi, Michael, (1966), The tacit dimension, Garden City, N.Y.: Doubleday.

Pondy, Louis R.; Boland, Richard; Thomas, Howard, (1988), Managing Ambiguity and Change, New York: Wiley.

Porac, Joseph F., Thomas, Howard, Baden-Fuller, Charles, (1989), "Competitive groups as cognitive communities: The case of Scottish knitwear manufacturers," Journal of Management Studies, 26:4, pp. 397-416.

Quinn, R.E., Cameron K.S. (Eds.), (1988), Paradox and Transformation, Cambridge, MA: Bollinger.

Reber, Arthur S. (1967), "Implicit Learning of Artificial Grammars," Journal of Verbal Learning and Verbal Behavior, Vol. 6, pp. 317-327.

Reber, Arthur S. (1969), "Transfer of syntatic structure in synthetic languages," Journal of Experimental Psychology, 81, pp. 115119.

Reber, Arthur S., (1993), Implicit learning and tacit knowledge: an essay on the cognitive unconscious, Oxford psychology series no. 19, Oxford: Oxford University Press.

Reber, Arthur. S., Lewis, S., (1977), "Toward a theory of implicit learning: The analysis of the form and structure of a body of tacit knowledge," Cognition, 5, pp. 333-361.

Rose, A., (1992, January), "Framing Our Experience: Research Notes on Reflective Practice," Adult Learning, Vol. 3, no. 4, p. 5.

Rosset, Clement (1977), Le Réel: Traité de l'idiotie, Paris: Editions de Minuit, 1977.

Rosset, Clement, (1985), Le réel et son double: Essai sur l'illusion, Paris: Gallimard, 1985.

Ruddick, William, (1988), "Social self-deceptions," in McLaughin B.P., Oksenberg Rorty A. (Eds.), Perspectives on Self-Deception, Berkeley: University of California Press, pp. 380-389.

Ryle, Gilbert, (1945), "Knowing How and Knowing That," Proceedings of the Aristotelian 
Society, Vol. XLVI, 1945/46, pp. 1-16, reprint in Ryle Gilbert, Collected Papers, London: Hutchinson, 1971. See also Ryle, The Concept of Mind, London: Hutchinson, 1949.

Sandelands L.E., Stablein R.E. (1987), "The Concept of Organization Mind," Research in the Sociology of Organizations, Volume 5, Jai Press, pp. 135-161.

Sanders, Andy F., (1988), Michael Polanyi's postcritical epistemology: a reconstruction of some aspects of 'tacit knowing', Amsterdam: Ro-dopi.

Schon, D., (1983), The Reflective Practitioner, New York: Basic Books.

Schon, D., (1988), Educating the Reflective Practitioner, San Francisco: JosseyBass.

Scribner, S. (1986), "Thinking in action: Some characteristics of practical thought," in Sternberg R. and Wagner R.K. (Eds.), Practical Intelligence: Nature and origins of competence in everyday world, Cambridge: Cambridge University Press, pp. 13-30.

Shenkar, Oded; Zeira, Yoram, (1992), "Role conflict and role ambiguity of chief executive officers in international joint ventures," Journal of International Business Studies, vol. 23 no. 1, pp. 55-75.

Simmel, Georg , (1908), "The sociology of secrecy and of secret societies," in Sozioliogie (in German), Chapter V, pp. 337-402.

Simmel, Georg, (1906, January), "The Sociology of Secrecy and of Secret Societies," The American Journal of Sociology, Vol. XI, n ${ }^{\circ}$, January 1906.

Spender, J.C., (1993), "Competitive advantage from tacit knowledge: Unpacking the concept and its strategic implications," Academy of Management Proceedings, Best Paper Series, Atlanta, August 8, 1993.

Spender, J.C., (1994), "Workplace cognition: The individual and collective dimensions," Research Paper, for the 2nd International Workshop on Managerial and Organiza-tional Cognition, Brussels, May 1994.

Starbuck, W.H. (1983), "Organizations as action generators," American Sociological Review, Vol. 48, pp. 91-102.

Starbuck W.H. (1988), "Surmounting Our Human Limitations," in Quinn R. and Cameron
K. (Eds.), Paradox and Transformation: Toward a Theory of Change in Organization and Management, Cambridge, MA: Ballinger.

Starbuck, W.H., Miliken Frances J., (1988a), "Challenger: Fine-tuning the odds until something breaks," Journal of Management Studies, Vol. 25, No. 4, (Juillet), pp. 319-340.

Starbuck W.H., Miliken F.J., (1988b) "Executives' Perceptual Filters: What They Notice and How They Make Sense," in D. Hambrick (ed.), The Executive Effect: Concepts and Methods for Studying Top Managers, Greenwich, CT: JAI Press, pp. 35-65.

Teece, Donald J. (1987), "Profiting from technological innovation," in Teece, D.J. (Ed.), The Competitive Challenge, Cambridge, MA: Ballinger Publications, pp. 185219.

Thorndike E.L. \& Rock, R.T., Jr. (1934), "Learning without awareness of what is being learned or intent to learn it," Journal of Experimental Psychlogy, pp. 1-19.

Torff, Bruce, (1993), Implicit learning and tacit knowledge: a literature review, Qualifying paper, Harvard Graduate School of Education, book format, 65 pages.

Turner, Stephen P., (1994), The social theory of practices: tradition, tacit knowledge and presuppositions, Chicago: University of Chicago Press.

Uleman, J.S. \& Bargh, J.A. (1989), Unintended Thought, New York: Guilford.

Vygotsky, L.S. (1962), Thought and language, Cambridge, MA: MIT Press.

Wagner, Richard K., (1991), Tacit knowledge inventory for managers: test booklet, San Antonio, TX.: Psychological Corp.

Wegner, D.M., Vallacher, R.R., (1977), Implicit Psychology: An introduction to social cognition, New York: Oxford University Press.

Weick, Karl. E., Roberts, Karlene H. , (1993), "Collective mind in organizations: Heedful interrelating on flight decks," Administrative Science Quaterly, September, Vol. 38, No. 3, pp. 357.

Weick, Karl E., (1986), "Interpretive sources of high reliability: Remedies for normal acci- 
dents," paper presented at Harvard University, April 11, 27 pages.

Weick, Karl E., (1989), "Theory Construction as Disciplined Imagination," Academy of Management Review, Volume 14, No 4,pp. 516-531.

Winter, Sydney G., (1987), "Knowledge and competence as strategic asset" in Teece, D.J. (Ed.), The Competitive Challenge, Cambridge, MA: Ballinger Publications, pp. 159-184.
Yin, Robert (1984), Case Study Research: Design and Methods, Applied Social Research Method Series, Volume 5, Beverly Hills, CA: Sage Publications.

Young, Raymond W., (1989), Tacit knowledge: group differences in the work place, Thesis (M.S. in Ed.)--Southern Illinois University at Carbondale, Ill.

Zand, Dale E. (1981), Information, Organization and Power: Effective Management in the Knowledge Society, New York: McGraw-Hill, 1981, pp. 57-88.

\section{LIST OF FIGURES}

Fig. 1: Triangulation of qualitative methods

Fig. 2: Transitions from tacit to explicit and vice-versa.

Fig. 3: An integrative framework to analyze transitions of knowledge types

Fig. 4: An augmented and completed matrix of knowledge modes

Fig. 5: Struggling with ambiguity at Indosuez

Fig. 6: Dominant knowledge modes in Indosuez' struggle with ambiguity

Fig. 7: Conventional scheduling process

Fig. 8: The new scheduling process

Fig. 9: Struggling with ambiguity at Qantas

Fig. 10: Dominant knowledge modes in Indigo's struggle with ambiguity

Fig. 11: Struggling with ambiguity at Pechiney (Guinea)

Fig. 12: Dominant knowledge modes in Pechiney's struggle with ambiguity

Fig. 13: Struggling with ambiguity at Indigo

Fig. 14: Dominant knowledge modes in Indigo's struggle with ambiguity 